$9-2008$

\title{
Water and Sediment Discharge from Small Mountainous Rivers, Taiwan: The Roles of Lithology, Episodic Events, and Human Activities
}

\author{
S. J. Kao
}

John D. Milliman

Virginia Institute of Marine Science

Follow this and additional works at: https://scholarworks.wm.edu/vimsarticles

Part of the Geology Commons

\section{Recommended Citation}

Kao, S. J. and Milliman, John D., "Water and Sediment Discharge from Small Mountainous Rivers, Taiwan: The Roles of Lithology, Episodic Events, and Human Activities" (2008). VIMS Articles. 1822.

https://scholarworks.wm.edu/vimsarticles/1822 


\title{
Water and Sediment Discharge from Small Mountainous Rivers, Taiwan: The Roles of Lithology, Episodic Events, and Human Activities
}

\author{
S. J. Kao, ${ }^{1}$ and J. D. Milliman ${ }^{2}$ \\ Research Center for Environmental Changes, Academia Sinica, Taiwan; and State Key Laboratory of Marine \\ Environmental Science, Xiamen University, Xiamen, China \\ (e-mail: sikao@gate.sinica.edu.tw)
}

\begin{abstract}
A B S T R A C T
Taiwan's natural setting creates highly vulnerable watersheds whose rivers discharge disproportionately large quantities

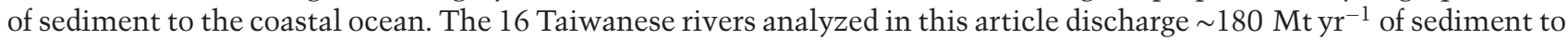
the coastal ocean, although totals over the past 20 years have varied between 16 and $440 \mathrm{Mt} \mathrm{yr}^{-1}$. The mean annual sediment yield of $9500 \mathrm{t} \mathrm{km}^{-2} \mathrm{yr}^{-1}$ for the 16 rivers is 60 -fold greater than the global yield of $150 \mathrm{t} \mathrm{km}^{-2} \mathrm{yr}^{-1}$, but mean yields for the individual rivers vary by more than 2 orders of magnitude, from 500 to $71,000 \mathrm{t} \mathrm{km}^{-2} \mathrm{yr}^{-1}$. Most sediment erosion and delivery occur in response to typhoon-generated floods, as evidenced by the fact that $>75 \%$ of the long-term flux occurs in $<1 \%$ of the time, about one-third of which reaches hyperpycnal concentrations. Detailed analysis of the 16 watersheds reveals little evidence of any single environmental factor that controls sediment load. The Erren, the highest-yield river on Taiwan, drains an erodible but low-gradient watershed with relatively low runoff. In contrast, three east coast rivers, the Hoping, the Hualien, and the Beinan, have high sediment yields that may be explained by relatively frequent earthquakes coupled with high runoff. Farming and urbanization also have elevated sediment yields in eastern watersheds, whereas Holocene sediments buried in the Taiwan Strait suggest that present-day sediment loads of the western rivers may be no higher than prehuman levels.
\end{abstract}

\section{Introduction}

A short article by Yuan-Hui Li in 1976 changed the way many Earth scientists, particularly those in western countries, view landscape denudation and the delivery of fluvial sediment to the global ocean. Before Li's article, both concepts were derived in large part from measurements on large rivers, particularly those draining Europe and North America (e.g., Fournier 1949, 1960; Holeman 1968; Lisitzin 1972), which at the time provided the most accessible and reliable data. Due to their large drainage basins, often low elevations, and relatively resistant pre-Mesozoic lithologies, many of these rivers have low sediment yields (see Syvitski and Milliman 2007); most Russian Arctic and northern European rivers, for example, have yields of $<20 \mathrm{t} \mathrm{km}^{-2} \mathrm{yr}^{-1}$.

\footnotetext{
2008.

Manuscript received February 28, 2008; accepted May 19,

${ }^{1}$ Author for correspondence: P.O. Box 1-55, Nangang, Taipei, Taiwan.

2 School of Marine Science, College of William and Mary, Gloucester Point, Virginia 23062, U.S.A.
}

Many Asian rivers, whose sediment yields are considerably higher by virtue of draining monsoondominated mountains, were too inadequately monitored by the early 1970s to provide reasonable long-term estimates of their sediment discharge and sediment yield.

Li's article cited sediment yields from Taiwanese rivers as high as $20,000 \mathrm{t} \mathrm{km}^{-2} \mathrm{yr}^{-1}$, roughly 2 orders of magnitude greater than the global average, and he argued that this in large part reflected a response to Taiwan's rapid uplift. Soon after Li's study, Adams (1980) and Griffiths (1981) in New Zealand, Jansen (1979) in Japan, and Pickup (1980) in New Guinea showed that other small rivers draining high-standing islands also can generate sediment yields exceeding $2000 \mathrm{t} \mathrm{km}^{-2} \mathrm{yr}^{-1}$. The suggestion of high sediment yields from small mountainous rivers prompted Milliman and Syvitski (1992), Summerfield and Hulton (1994), Milliman et al. (1999), and, more recently, Syvitski and Milliman (2007) to point out their relevance in global sediment dis- 
charge. Milliman et al. (1999), for instance, estimated that rivers in the high-standing islands in Oceania and New Guinea may discharge as much as $\sim 20 \%-25 \%$ of the total sediment flux to the global ocean. The mass flux from such small rivers also has potential biogeochemical significance since many of these rivers discharge onto narrow shelves, facilitating sediment bypass to the deep sea and thereby enhancing the chance for organic carbon sequestration (Milliman 1995; Nittrouer et al. 1995; Carey et al. 2002; Lyons et al. 2002; Kao et al. 2006; Leithold et al. 2006).

As the importance of small mountainous rivers in global sediment discharge has gradually been accepted, Taiwan has remained on center stage in the documentation of processes and factors that control rapid bedrock incision, bank erosion, sediment supply, and down-gradient removal (e.g., Hovius et al. 2000; Hartshorn et al. 2002; Dadson et al. 2003; Fuller et al. 2003; Leithold et al. 2006). The oblique collision between the Philippine and Asian plates results in uplift rates of 5-7 $\mathrm{mm} \mathrm{yr}^{-1}$ (Liu 1982). High tectonic activity and rapid uplift, steep landscape morphology, highly erodible rocks, and heavy typhoon-induced rains collectively promote the oft-cited high rates of sediment production.

Somehow lost in this story has been the fact that Li based his story on data derived from "Annual Sediment Loads" cited in the annual reports of the Taiwan Water Resources Planning Committee (WRPC), renamed the Water Resources Agency (WRA). While this database represents one of the longest databases available to the scientific public, methods of computation, unfortunately, are not described in WRPC/WRA annual reports. The veracity of the published sediment loads is called into question by the fact that reported annual sediment loads in the Taiwanese rivers have remained remarkably constant from year to year even though annual discharge from some rivers can vary by a factor of 10 or more (Kao and Liu 2001; Kao et al. 2005; Milliman and Kao 2005).

The interest in Taiwanese rivers, moreover, has increased by the heightened interest in hyperpycnal events, by which fluvial plumes become sufficiently dense (defined here as sediment concentration $\left[Q_{\mathrm{c}}\right]>40 \mathrm{~g} \mathrm{~L}^{-1} \mid$ to sink below oceanic waters, thereby facilitating a direct escape to offshore waters by minimizing normal estuarine mixing (Mulder and Syvitski 1995; Mulder et al. 2003; Warrick and Milliman 2003). Hyperpycnal flows, however, tend to be short-lived (hours to days), so routine sampling often fails to capture the event (Milliman and Kao 2005). Despite the lack of directly measured concentrations during hyperpycnal events, a number of authors have noted the potentially important role that rare and extreme events may have on long-term average sediment flux (Mulder and Syvitski 1995; Syvitski and Morehead 1999; Meybeck et al. 2003; Mulder et al. 2003; Warrick and Milliman 2003; Kao et al. 2005). As will be seen below, this is particularly critical in understanding the flux and fate of sediments discharged from Taiwanese rivers.

In this article, we calculate the sediment discharge for 16 major Taiwanese rivers (fig. 1), using rating curves that take into account both the seasonal and episodic flow of these rivers (Kao et al. 2005). Although many of our calculated values are not dissimilar to those reported by Li (1976), our discussion here centers on three relevant topics not raised by Li: $(a)$ the episodicity of sediment discharge, particularly in response to typhoons and earthquakes; $(b)$ the importance of hyperpycnal discharge in some (but not all) Taiwanese rivers; and $(c)$ the relative importance of gradient, lithology, and runoff as well as the impact of anthropogenic activities, particularly land use, in controlling denudation and sediment delivery. This latter point, we contend, is particularly relevant in Taiwan, as prehuman denudation rates in at least some of the watersheds almost certainly were lower, perhaps much lower, than suggested by present-day sediment discharges.

\section{Taiwan Rivers}

The WRA archive of hydrological data for some rivers extends as far back as the late 1940s. From this database we have documented 16 primary rivers (fig. 1) whose total basin areas range between 350 and $3250 \mathrm{~km}^{2}$ (table 1); collectively, these rivers drain $18,700 \mathrm{~km}^{2}$, half of Taiwan's total land area. Record lengths of the 16 rivers range between 24 and 57 years, and the total number of suspended sediment measurements for each river ranges from 388 to 1566 , with an average of 20 measurements per river per year (see table 1). The WRA has used the standard US DH-48 depth-integrated suspended sediment sampler recommended by the U.S. Federal Interagency Sedimentation Project (http://fisp .wes.army.mil//. No uncertainty value has been provided for measurements across the river section in WRA's reports.

Other than the Beigang and Erren, the rivers drain mountainous terrain, seven draining elevations higher than $3000 \mathrm{~m}$ (table 1). With the exception of the two low-elevation $(516$ and $460 \mathrm{~m}$, respectively) and low-gradient rivers $(0.6 \%, 0.7 \%)$, the rivers have gradients $>1.8 \%$, with the steepest 


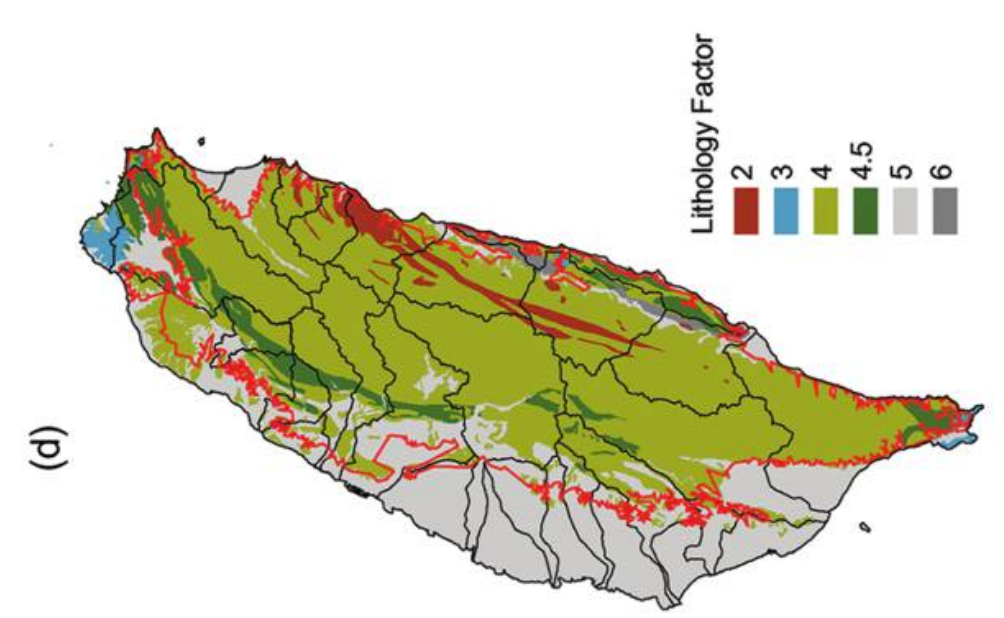

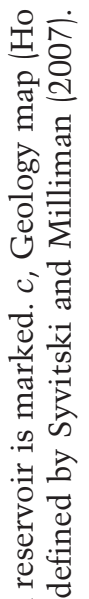

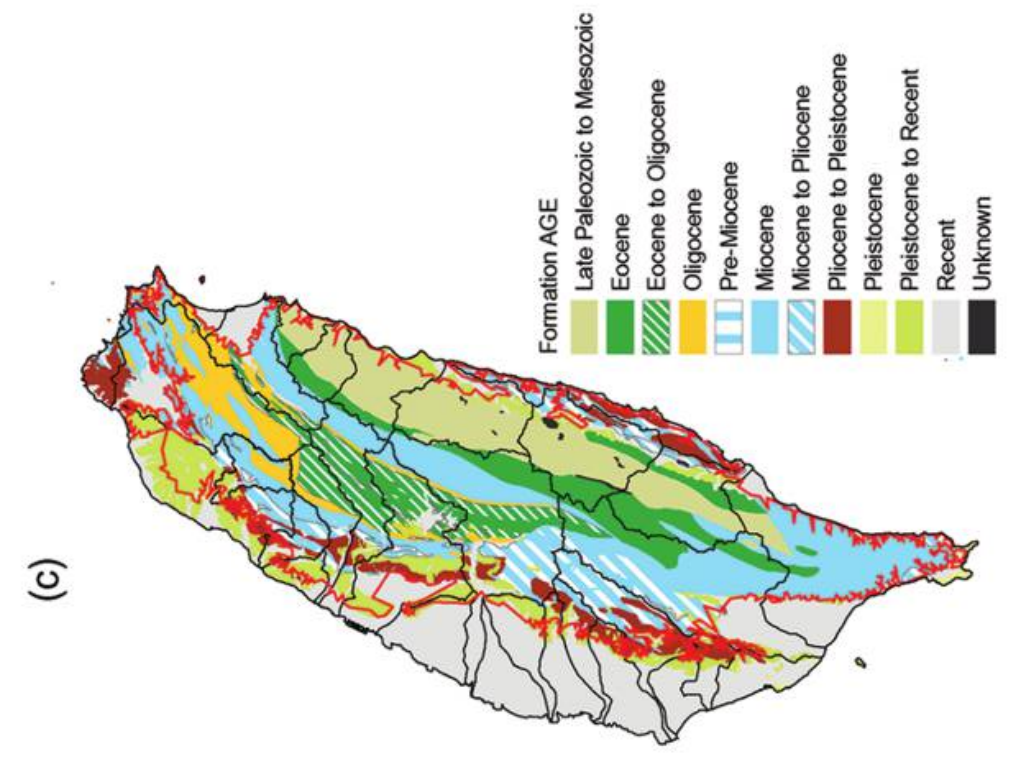

言

D.

$\mathrm{N}$

क्ष

离

我。

可

苞

है ज

क

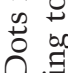

ํํํ

.

콥 콤

क

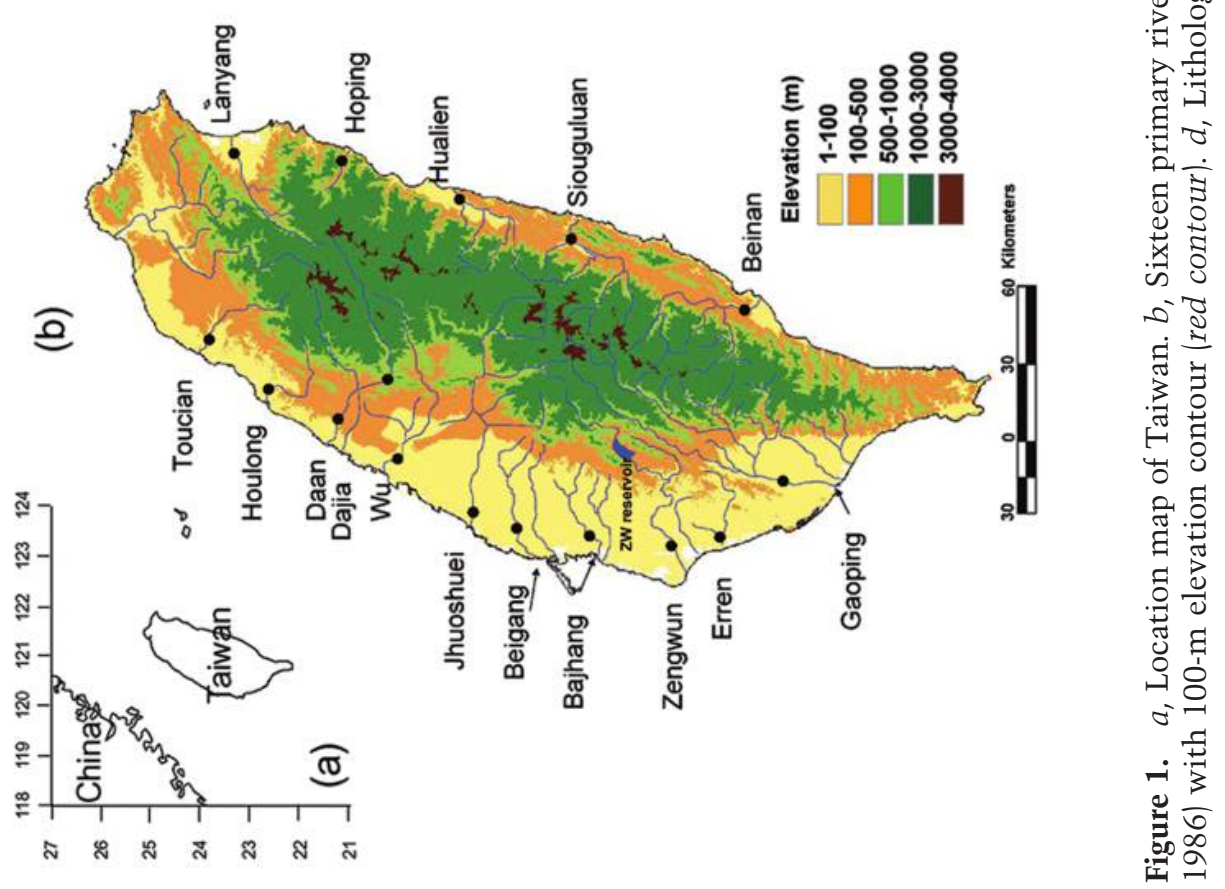




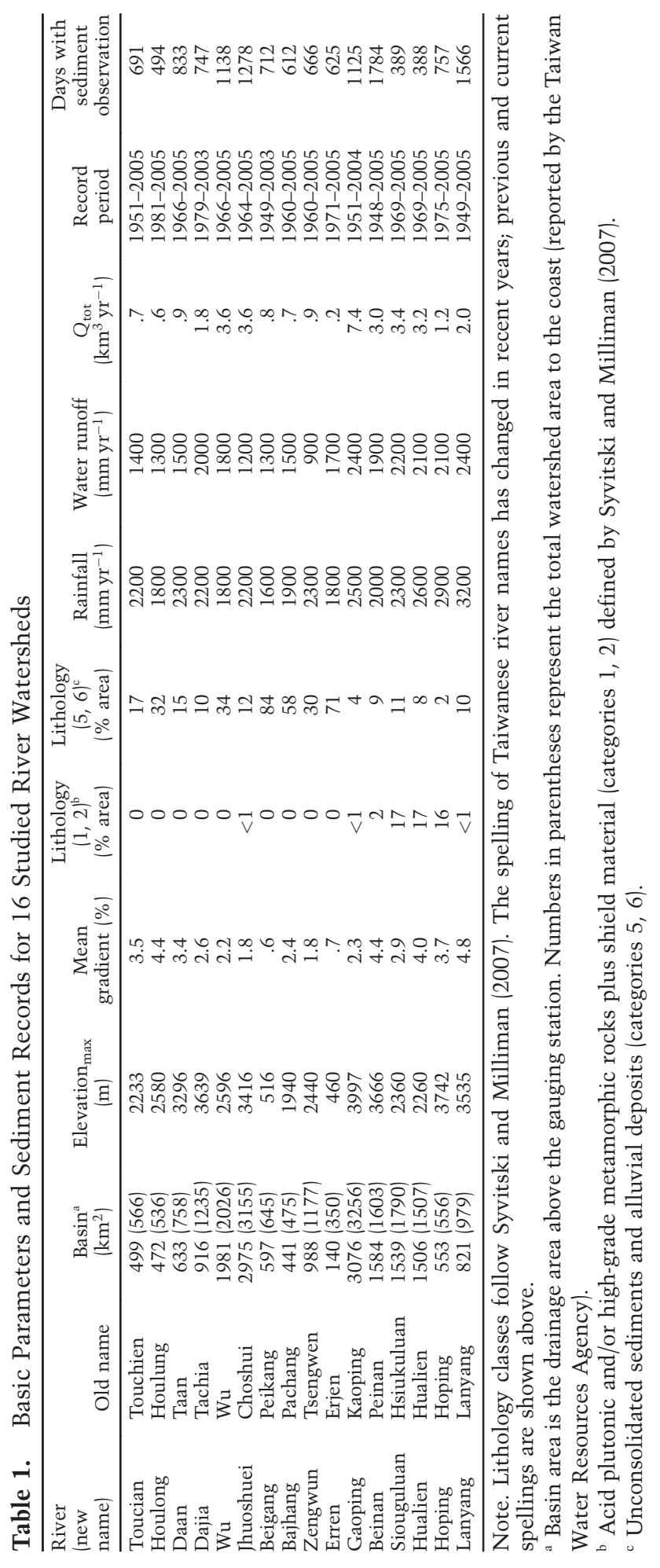


gradient rivers being in the north and east (table 1). The eastern side of the Central Range contains the only pre-Mesozoic rocks found on Taiwan, rocks to the west becoming progressively younger; elevations $<100 \mathrm{~m}$ are predominantly late Quaternary in age (cf. fig. $1 b$ and $1 c$ ).

For purposes of delineating the nature of the source rocks for the 16 watersheds, we assumed that (with the notable exception of the Erren River; see below) the sediments transported by the rivers come from elevations higher than $100 \mathrm{~m}$; lower elevations are assumed to be primarily sinks for the sediments eroded up-gradient. Based on the lithologic character of the rocks, we find that only the three softest lithologic classes of the six classes listed by Syvitski and Milliman (2007) are quantitatively important on Taiwan. The hardest class (1: hard, acid plutonic and/or high-grade metamorphic rocks) is absent, and two next-hardest classes-(2: hard lithologies including shield material, and 3: mostly basaltic and carbonate rocks) —account for only $4 \%$ of the rocks at elevations $>100 \mathrm{~m}$. Rather, we find a prominence of softer lithologies (class 4) and, particularly on the western coastal plains, the dominance of unconsolidated sediments and alluvial deposits (class 5), with local occurrences of exceptionally weak material, such as crushed rock (class 6, according to Syvitski and Milliman 2007; fig. 1). We added a seventh category (class 4.5, strata containing sandstone, shale, and mudstone) and then compared area coverage of various lithologies within each watershed (see table 1). Because older, more resistant rocks tend to dominate the higher elevations in Taiwan, particularly eastern Taiwan, it is not surprising to see a close relationship between the prominence of erodible rocks and watershed elevation (fig. 2), with higherelevation rivers as well as eastern rivers draining older and more resistant rocks.

Long-term basin-integrated rainfall in Taiwan ranges from 1600 to $3200 \mathrm{~mm} \mathrm{yr}^{-1}$ but exceeds $4000 \mathrm{~mm}$ in the mountains. Because eastern rivers are more mountainous (fig. 1), rainfall and runoff tend to be greater than in western rivers, whose drainage basins also incorporate coastal lowlands; the runoff from eastern rivers approaches or exceeds $2000 \mathrm{~mm} \mathrm{yr}^{-1}$ (table 1). Precipitation is highly seasonal, with July-October rainfall accounting for as much as $75 \%$ of the annual total in the south and east (fig. 3). During low-rainfall months, mean daily discharge for most rivers generally averages less than $10-50 \mathrm{~m}^{3} \mathrm{~s}^{-1}$, whereas during high-rainfall months, it can exceed $1000-10,000 \mathrm{~m}^{3} \mathrm{~s}^{-1}$.

The seasonal weather pattern is accentuated by the periodic advent of typhoons. Lying in the typhoon alley of the western Pacific, Taiwan averages

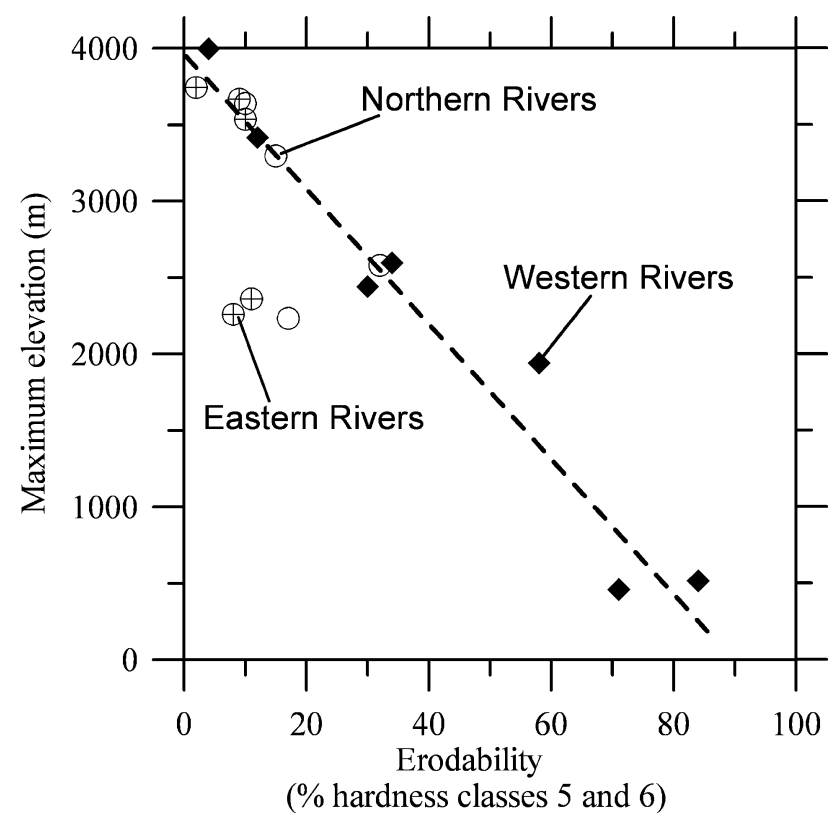

Figure 2. Correlations between maximum elevation and rock erodibility (\% hardness classes 5 and 6 ; see text) in 16 watersheds.

four typhoons annually, mostly between June and September, although some have occurred as late as November. Individual rainfall events associated with typhoons can bring $>500 \mathrm{~mm}$ total rainfall within one or two days, often with dramatic increases in river discharge (see below). Short-term discharge can exceed $10,000 \mathrm{~m}^{3} \mathrm{~s}^{-1}$, approaching or surpassing $20,000 \mathrm{~m}^{3} \mathrm{~s}^{-1}$ in some of the larger rivers.

\section{Calculating Sediment Discharge}

Role of Seasonal Fluctuations and Episodic Events. Estimating suspended sediment discharge is a particularly daunting task in rivers that experience highly fluctuating discharge and changing watershed conditions (Walling 1977, 1983, 1999; Horowitz 2003). Perhaps nowhere is this problem more acute than in Taiwan, where dry- and wet-season discharges can vary by 1-2 orders of magnitude (fig. 4). Typhoons can further exacerbate seasonal fluctuations, with typhoon-induced floods being capable of increasing river discharge by $2-3$ orders of magnitude in a single day (see below; fig. 5). It is not atypical for such events to account for a major part of annual sediment discharge even though they may last only several hours to a few days.

According to the WRA's database, water discharge $(Q)$ and corresponding sediment concentra- 


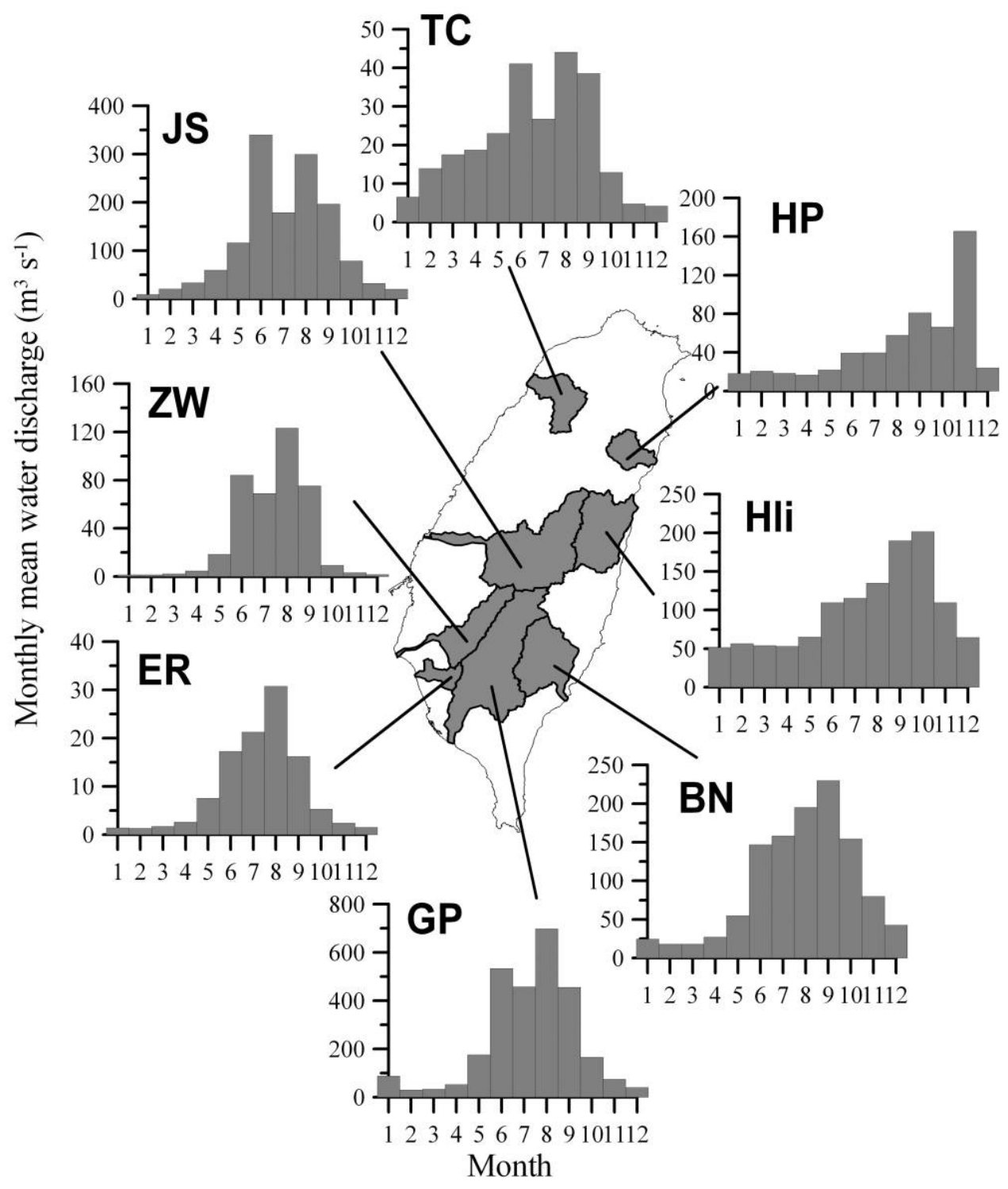

Figure 3. Mean monthly discharge for eight representative Taiwanese rivers. Peak discharge in eastern rivers tends to occur later in the year. River names: $B N=$ Beinan, $E R=$ Erren, $G P=$ Gaoping, $H l i=$ Hualien, $H P=$ Hoping, $I S=$ Jhuoshuei, $T C=$ Toucian, and $Z W=$ Zengwun.

tions $\left(Q_{c}\right)$ in all 16 rivers except the Dajia have reached sediment concentrations of $10 \mathrm{~g} \mathrm{~L}^{-1}$, and eight rivers often have exceeded sediment concentrations of $40 \mathrm{~g} \mathrm{~L}^{-1}$ (e.g., fig. 6 for Jhuoshuei). The highly variable $Q_{\mathrm{c}}$ levels, coupled with a $>4$-orderof-magnitude increase in $Q$ (fig. 4), can result in as much as a 10-order-of-magnitude increase in sediment discharge $\left(Q_{\mathrm{s}}\right)$. Moreover, erodibility can change in response to both anthropogenic and natural events, such as road construction or landslides (Hovius et al. 2000; Dadson et al. 2003). Rains associated with Typhoon Toraji (August 2001), the first major typhoon to strike central Taiwan after the Chichi earthquake (October 1999), for example, caused 20,000 soil and bedrock landslides in the Jhuoshuei watershed alone, resulting in sediment concentrations in the river of $200 \mathrm{~g} \mathrm{~L}^{-1}$ and total sediment transport of $>200 \mathrm{Mt}$ in just three days (Dadson et al. 2005).

Because the wide scatter between $Q_{c}$ and $Q$ (fig. 6) reflects the variety of short-term natural and anthropogenic impacts that can dictate sediment delivery (Walling 1977, 1983), it is impossible to predict $Q_{\mathrm{c}}$ with any degree of accuracy for a given water discharge by incorporating all suspended sediment data into a single rating curve. Rather, a 


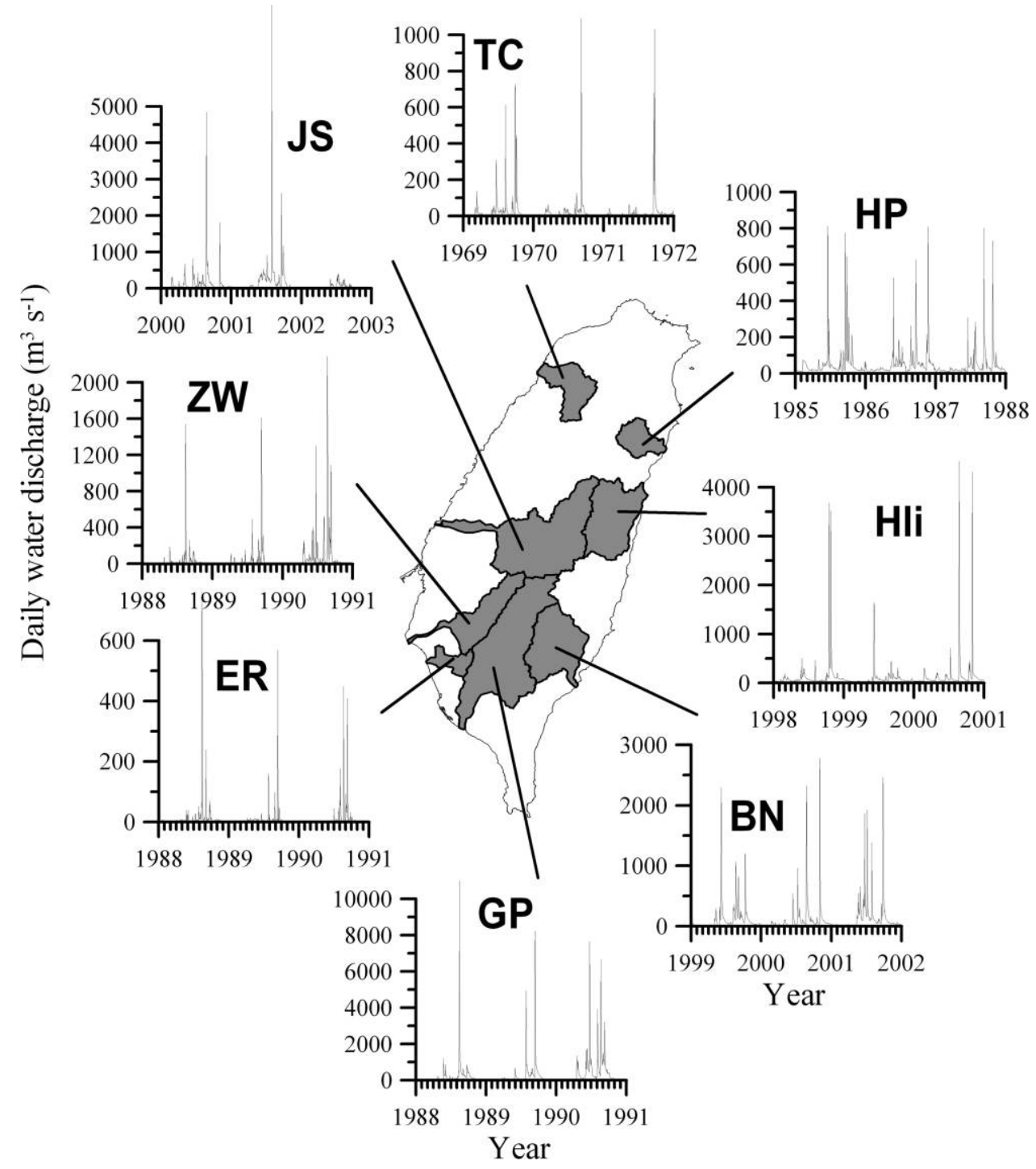

Figure 4. Three-year records of daily discharge for eight Taiwanese rivers; note the significance of episodic events, often lasting only 1 or $2 \mathrm{~d}$, in all rivers. River names: $B N=$ Beinan, $E R=$ Erren, $G P=$ Gaoping, Hli $=$ Hualien, $H P=$ Hoping,$I S=$ Jhuoshuei, $T C=$ Toucian, and $Z W=$ Zengwun.

proper estimator is required to evaluate relative long-term contributions from high- and low-flow discharges.

Deriving a Meaningful Sediment Rating Curve. The WRA uses a flow-duration rating curve (FDRC) to estimate sediment load, in which only one single rating curve is constructed from the cumulative data set (e.g., fig. 4); this basically assumes constant watershed conditions throughout the entire period of record, thereby leaving water discharge as the controlling factor in governing sediment load. This precludes delineation of any short-term variability in sediment flux, such as that caused by typhoons, earthquakes, or human activities (Kao et al. 2001, 2002, 2005). Recognizing the importance of typhoon-related transport, however, the WRA has biased its routine suspended sediment sampling toward the high-discharge months between July and September.

To reduce the potential bias of uneven sampling frequency in calculating the long-term mean annual sediment load, Dadson et al. (2003) developed a monthly weighted average (MWA) method. The MWA method gives equal weight to each monthly average rather than to each observation. Similar to FDRC, the MWA provides only a long-term mean value that cannot delineate any short-term variability in sediment flux (Kao et al. 2005). 

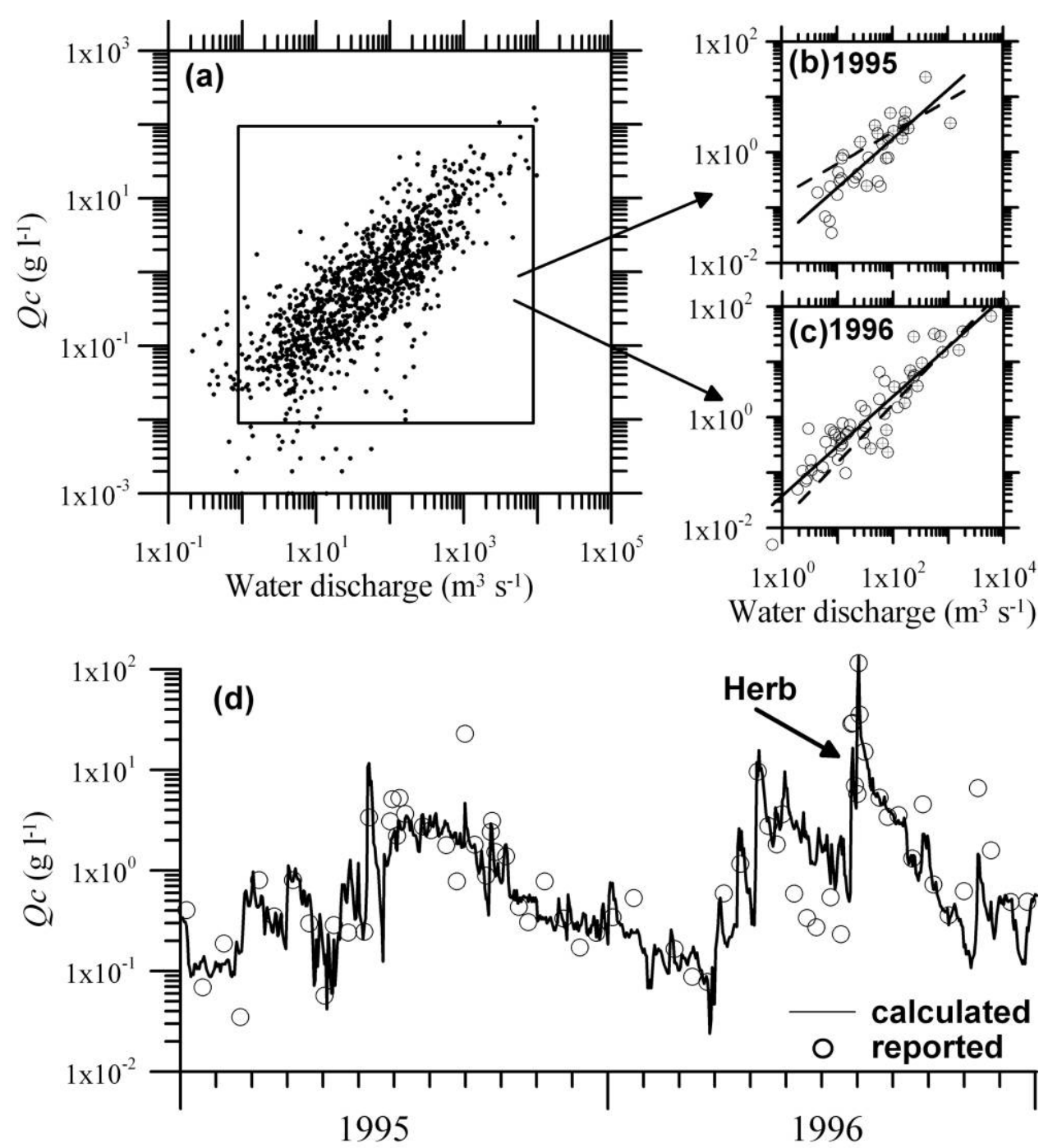

Figure 5. $a$, Scatterplot of all reported sediment concentrations $\left(Q_{c}\right.$, in $\left.\mathrm{g} \mathrm{L}^{-1}\right)$ and corresponding water discharge rates (10 $\mathrm{g} \mathrm{L}^{-1}$ is shown for reference) of the Jhuoshuei River. b, Scatterplot of 1995 data. Rating curves for dry (crossed circles) and wet (open circles) periods are shown. $c$, Scatterplot of 1996 data. $d$, Calculated (line) and reported (circles) sediment concentrations during 1995-1996.

By contrast, Kao et al. (2005) developed stratified time-frame rating curves for each Taiwanese river that reflect yearly and seasonal changes in $Q$ and $Q_{\mathrm{c}}$. Using a FORTRAN program that incorporates limited-range extrapolation in water discharge, representative data points, and meaningful regressions, Kao et al. (2005) determined that the optimal procedure to develop meaningful rating curves was to separate yearly data into low-flow (NovemberMay) and high-flow (July-October) months. The two annual rating curves were then applied to daily (and during peak-flow events, hourly) discharges to calculate annual suspended sediment load. A bias-correction factor also was introduced to reduce residuals; when combined with hourly discharge data, they successfully predicted sediment fluxes and concentrations in response to episodic events, particularly during typhoons. Annual sediment loads calculated using $Q_{c}$ values derived from seasonal rating curves generally agree closely with loads derived from event-based rating curves (Milliman and Kao 2005); because of the greater ease of calculation, we have used seasonal rating curves to calculate the $Q_{\mathrm{c}}$ and thereby $Q_{\mathrm{s}}$ cited in this article.

The reported $Q_{\mathrm{c}}$ in the Jhuoshuei River for period 1964-2005 (total 1278 samples; table 1) shows a dynamic range over 6 orders of magnitude, corresponding with $>4$ orders variation of $Q$ (fig. 6). 


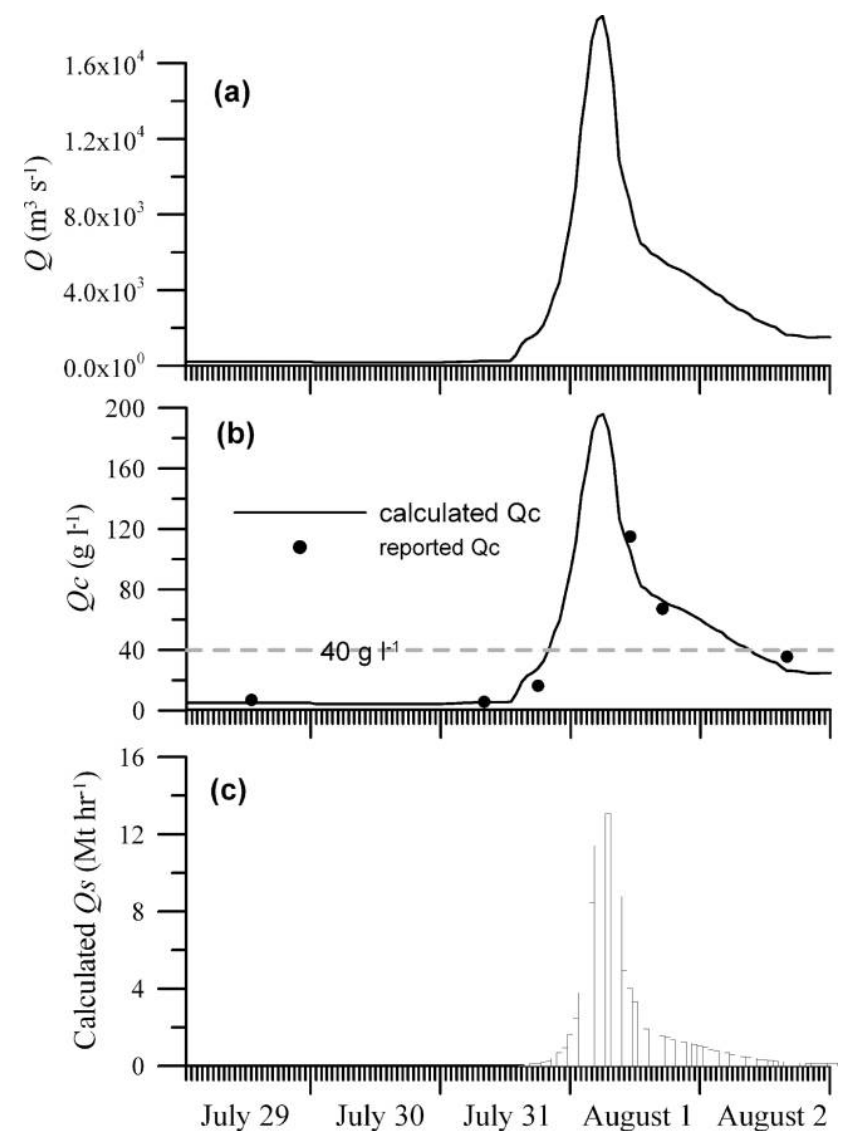

Figure 6. Hourly water discharge $(a)$, calculated and measured suspended sediment concentrations $(b)$, and calculated sediment loads $(c)$ in the Jhuoshuei River during Super-Typhoon Herb, July 31-August 2, 1996. After Milliman and Kao (2005).

Calculated $Q_{\mathrm{c}}$ values derived from our stratified time-frame rating curves agree well with WRAreported values (fig. 6). Most data points, particularly those at high-loading conditions, fall tightly along the 1:1 linear line (Milliman and Kao 2005; Milliman et al. 2007), indicating that the method can predict loads at high-flow conditions. A 2-yr example of the Jhoushuei River (fig. 6) shows the close correlation between calculated and reported $Q_{c}$ over a dynamic range of flow conditions.

Use of hourly water-discharge peak events is critical in estimating sediment loads (Kao and Liu 2001; Kao et al. 2005; Milliman and Kao 2005). Using daily discharge for Super-Typhoon Herb, which lasted only $3 \mathrm{~d}$ (fig. 5), for example, would preclude quantifying dynamic changes in sediment concentration (fig. 5) or load (fig. 5). Most importantly, hourly discharge data allow us to identify hyperpycnal events (dashed line in fig. 5) and calculate their relative contribution to sediment load.

\section{Sediment Discharge from Taiwanese Rivers}

Mean annual sediment discharge for the 16 Taiwanese rivers ranges from $0.5 \mathrm{Mtyr}^{-1}$ (Dajia River, based on $25 \mathrm{yr}$ of data) to $40 \mathrm{Mtyr}^{-1}$ (Jhuoshuei River, based on $42 \mathrm{yr}$ of data (tables 2,3). Mean annual sediment discharge from the 16 Taiwanese rivers is $\sim 180 \mathrm{Mt} \mathrm{yr}^{-1}$, similar to the $190 \mathrm{Mt} \mathrm{yr}^{-1}$ reported by $\mathrm{Li}$ and the WRA. Averaged over the drainage basin area upstream of the gauging station, the Dajia has the lowest sediment yield $\left(500 \mathrm{t} \mathrm{km}^{-2} \mathrm{yr}^{-1}\right), \sim 2$ orders of magnitude less than that of the Erren $\left(71,000 \mathrm{t} \mathrm{km}^{-2} \mathrm{yr}^{-1}\right.$; table 2), which drains particularly erodible terrain (Dadson et al. 2003). Sediment yield calculated relative to basin area higher than $100 \mathrm{~m}$, which provides a better estimate of denudation, shows that with the exception of the Dajia and Touchian (550 and $2300 \mathrm{t} \mathrm{km}^{-2} \mathrm{yr}^{-1}$, respectively) and the Erren $\left(120,000 \mathrm{t} \mathrm{km}^{-2} \mathrm{yr}^{-1}\right)$, most rivers have sediment yields between 3000 and $28,000 \mathrm{t} \mathrm{km}^{-2} \mathrm{yr}^{-1}$.

Average annual sediment yield for the 16 rivers is $9500 \mathrm{t} \mathrm{km}^{-2} \mathrm{yr}^{-1}$ (table 2), approximately 60-fold higher than the global average of $\sim 150 \mathrm{t} \mathrm{km}^{-2} \mathrm{yr}^{-1}$ (Milliman and Syvitski 1992). Due to their more mountainous, steeper-gradient drainage basins, east coast rivers have considerably higher yields (average of $12,000 \mathrm{t} \mathrm{km}^{-2} \mathrm{yr}^{-1} ; 13,000 \mathrm{t} \mathrm{km}^{-2} \mathrm{yr}^{-1}$ for elevations higher than $100 \mathrm{~m})$ than west coast rivers $\left(6800 \mathrm{t} \mathrm{km}^{-2} \mathrm{yr}^{-1}\right)$. Mean annual yield for island-wide basin areas higher than $100 \mathrm{~m}$ is $11,000 \mathrm{t} \mathrm{km}^{-2} \mathrm{yr}^{-1}$.

Only two rivers, Jhuoshuei and Zengwun, have calculated sediment loads $>10 \mathrm{Mt}$ different from the WRA estimates. In contrast, the cumulative loads for the 16 rivers calculated by the monthly weighted method of Dadson et al. (2003) are higher by a factor of 2 (360 $\mathrm{Mt} \mathrm{yr}^{-1}$; table 2). For large rivers such as Jhuoshuei, Zengwun, Gaoping, Beinan, Siouguluan, and Lanyang, the MWA method gives $50 \%-400 \%$ higher loads. The MWA-derived load for the Beinan of $88 \mathrm{Mtyr}^{-1}$ (Dadson et al. 2003), compared to $20 \mathrm{Mtyr}^{-1}$ using our method and that of the WRA, equates to mean $Q_{\mathrm{c}}$ of $30 \mathrm{~g} \mathrm{~L}^{-1}$, which seems unrealistically high since only 31 of the $1784(<2 \%)$ suspended sediment measurements taken in the Beinan since 1948 reached or exceeded that value.

\section{Controlling Factors}

Calculating a long-term sediment load for a river or group of rivers is clearly not as straightforward as dividing the cumulative long-term load by the number of years of measurement. How does one, for example, integrate into the long-term load the impact of a major natural event, such as an earth- 
Table 2. Long-Term Mean Sediment Loads (Mean \pm Residual Error; in Mt) and Yields for 16 Major Rivers Compared with Loads Estimated in Other Studies

\begin{tabular}{|c|c|c|c|c|c|c|c|c|c|}
\hline River & Min.-Max. & This study ${ }^{a}$ & WRA $^{\mathrm{b}}$ & MWA $^{\mathrm{c}}$ & $\begin{array}{l}\text { Li, Y. H. } \\
\text { (1976) }\end{array}$ & $\begin{array}{l}\text { Gauging } \\
\text { area }^{\mathrm{d}}\left(\mathrm{km}^{2}\right)\end{array}$ & $\begin{array}{l}\text { SS yield } \\
\left(\mathrm{t} \mathrm{km}^{2} \mathrm{yr}^{-1}\right)\end{array}$ & $\begin{array}{c}\text { Upstream } \\
\text { area } \\
(>100 \mathrm{~m})\end{array}$ & $\begin{array}{l}\text { SS yield } \\
(>100 \mathrm{~m})\end{array}$ \\
\hline Toucian & $.01-8.5$ & $1.1 \pm .2$ & 2.0 & 1.5 & 1.2 & 499 & 2300 & 481 & 2300 \\
\hline Houlong & $.05-14$ & $2.4 \pm .3$ & 3.3 & 2.9 & 4 & 472 & 5100 & 396 & 6100 \\
\hline Daan & $.07-24$ & $4.0 \pm .6$ & 3.6 & 7.1 & 3.5 & 756 & 6300 & 742 & 6300 \\
\hline Dajia & $.01-2.3$ & $.5 \pm .2$ & 2.6 & 1.0 & 2.4 & 1292 & 500 & 1238 & 550 \\
\hline Wu & $.48-38$ & $5.3 \pm 1.5$ & 5.8 & 9.8 & 6.7 & 1981 & 2700 & 1763 & 3000 \\
\hline Jhuoshuei & $2.9-263$ & $40 \pm 5.7$ & 52 & 54 & 54 & 2975 & 13,000 & 2903 & 14,000 \\
\hline Beigang & $.09-3.9$ & $1.4 \pm .3$ & 1.9 & 2.2 & 2 & 597 & 2300 & 179 & 7800 \\
\hline Bajhang & $.28-11$ & $2.5 \pm .5$ & 2.6 & 6.3 & 1.6 & 441 & 5700 & 230 & 11,000 \\
\hline Zengwun & $.34-110$ & $12 \pm 2.4$ & 23 & 25 & 17 & 988 & 12,000 & 912 & 13,000 \\
\hline Erren & $.04-51$ & $10 \pm 2.1$ & 4.5 & 30 & 4.2 & 140 & 71,000 & 83 & 120,000 \\
\hline Gaoping & $.67-110$ & $20 \pm 3.0$ & 23 & 49 & 29 & 3076 & 6500 & 2619 & 7600 \\
\hline Beinan & $.06-123$ & $20 \pm 2.9$ & 20 & 88 & 20 & 1584 & 13,000 & 1567 & 13,000 \\
\hline Siouguluan & $.24-44$ & $13 \pm 1.8$ & 15 & 22 & 12 & 1539 & 8500 & 1709 & 8500 \\
\hline Hualien & $.37-109$ & $25 \pm 3.3$ & 18 & 31 & 16 & 1506 & 17,000 & 1359 & 18,000 \\
\hline Hoping & $.08-51$ & $15 \pm 4.1$ & * & 15 & 10 & 553 & 27,000 & 545 & 28,000 \\
\hline Lanyang & $.13-49$ & $6.4 \pm 1.7$ & 5.8 & 17 & 6 & 821 & 7800 & 901 & 7800 \\
\hline Total & & 180 & 190 & 360 & 190 & & 9500 & & 11,000 \\
\hline
\end{tabular}

a The record period for each station was shown in table 1 .

${ }^{\mathrm{b}}$ Data from the Taiwan Water Resources Agency Hydrological Yearbooks, but we removed fractions of area extrapolation and bed load (see Kao and Liu 2001).

${ }^{c}$ MWA = monthly weighted average. Values are taken from Dadson et al. (2003), based on 1970-1999 data.

d Drainage area above the gauging station.

e Sediment yield based on gauging area. Total is a sediment-weighted average.

${ }^{\mathrm{f}}$ Sediment yield based on area $>100 \mathrm{~m}$ in elevation. Total is a sediment-weighted average.

quake or typhoon or a particularly long dry or wet period? Moreover, how do human activities, which can either increase (e.g., agriculture, road construction) or decrease (e.g., dam construction, irrigation) sediment erosion and transport, affect short-term and long-term sediment discharge?

Interannual variations in sediment discharge from Taiwanese rivers are particularly notable, with our records showing, for instance, annual discharge for the Jhuoshuei ranging from 2.9 to $263 \mathrm{Mt} \mathrm{yr}^{-1}$. Ranges for the Hualien, Erren, Beinan, and Gaoping are even greater: $<1-121,<1-75,<1-239$, and 0.6-92 $\mathrm{Mt} \mathrm{yr}^{-1}$, respectively. Total annual discharge from the 16 rivers between 1979 and 2005 ranged from 16 to $443 \mathrm{Mt} \mathrm{yr}^{-1}$. In the following paragraphs, we discuss three factors that are particularly important in understanding Taiwanese fluvial sediment discharge: episodic events, particularly typhoons

Table 3. Occurrence of Hyperpycnal Events and Their Related Sediment Discharge

\begin{tabular}{|c|c|c|c|c|c|c|}
\hline River & Record (yr) & $Q_{\mathrm{s}}\left(\mathrm{Mt} \mathrm{yr}^{-1}\right)$ & Years $_{\text {hyper }}$ & Hours $_{\text {hyper }}$ & $Q_{\text {s hyper }}\left(\mathrm{Mt} \mathrm{yr}^{-1}\right)$ & $\% Q_{\text {shyper }}$ \\
\hline Toucian & 55 & 61 & 4 & 24 & 10 & 16 \\
\hline Houlong & 25 & 60 & 3 & 9 & 5.5 & 9 \\
\hline Daan & 39 & 150 & 3 & 53 & 27 & 18 \\
\hline Dajia & 25 & 11 & 0 & 0 & 0 & 0 \\
\hline $\mathrm{Wu}$ & 40 & 210 & 2 & 17 & 44 & 21 \\
\hline Jhuoshuei & 42 & 1700 & 13 & 470 & 700 & 42 \\
\hline Beigang & 55 & 73 & 0 & 0 & 0 & 0 \\
\hline Bajhang & 46 & 120 & 1 & 3 & .89 & .76 \\
\hline Zengwun & 46 & 550 & 9 & 384 & 210 & 38 \\
\hline Erren & 35 & 340 & 26 & 1226 & 270 & 79 \\
\hline Gaoping & 54 & 1100 & 3 & 35 & 96 & 8.7 \\
\hline Beinan & 57 & 1200 & 25 & 512 & 390 & 34 \\
\hline Siouguluan & 37 & 490 & 7 & 106 & 110 & 22 \\
\hline Hualien & 37 & 910 & 17 & 274 & 470 & 51 \\
\hline Hoping & 29 & 440 & 13 & 1118 & 300 & 68 \\
\hline Lanyang & 56 & 360 & 8 & 195 & 83 & 23 \\
\hline Total & 678 & 7775 & 134 & $4426(.7 \% \mathrm{o})$ & 2716 & 35 \\
\hline
\end{tabular}

Note. $Q_{\mathrm{s}}=$ sediment flux.

a Time fraction of hyperpycnal flow in total record period (see text). 
and earthquakes; hyperpycnal events; and the impact from human activities.

Episodic Events. Intense typhoons, generally lasting 3-5 d, frequently are responsible much of the annual sediment transport in many Taiwanese rivers. During the three days of Super-Typhoon Herb (July-August 1996), for example, the Jhuoshuei River discharged $\sim 125 \mathrm{Mt}$ (mostly at hyperpycnal concentrations), 3 orders of magnitude greater than what the river transported during the 2 d before the typhoon (Milliman and Kao 2005) and roughly threefold higher than the river's mean an- nual load (figs. 6, 5). River discharge increased 2 orders of magnitude (from $\sim 200$ to $19,000 \mathrm{~m}^{3} \mathrm{~s}^{-1}$ ) in less than $18 \mathrm{~h}$, and suspended sediment concentrations increased from $\sim 3-4$ to $>200 \mathrm{~g} \mathrm{~L}^{-1}$. For the two and one-half days before Herb (fig. 5), calculated hourly sediment discharge was $\sim 2400 \mathrm{th}^{-1}$; at Herb's peak it was $13 \mathrm{Mth}^{-1}$. Before July 31 , the Jhuoshuei River's total sediment transport for 1996 had been $<3 \mathrm{Mt}$; on August 1 alone it transported $>100 \mathrm{Mt}$.

Daily sediment fluxes (fig. 7) illustrate the disproportional contribution of typhoon floods to an-

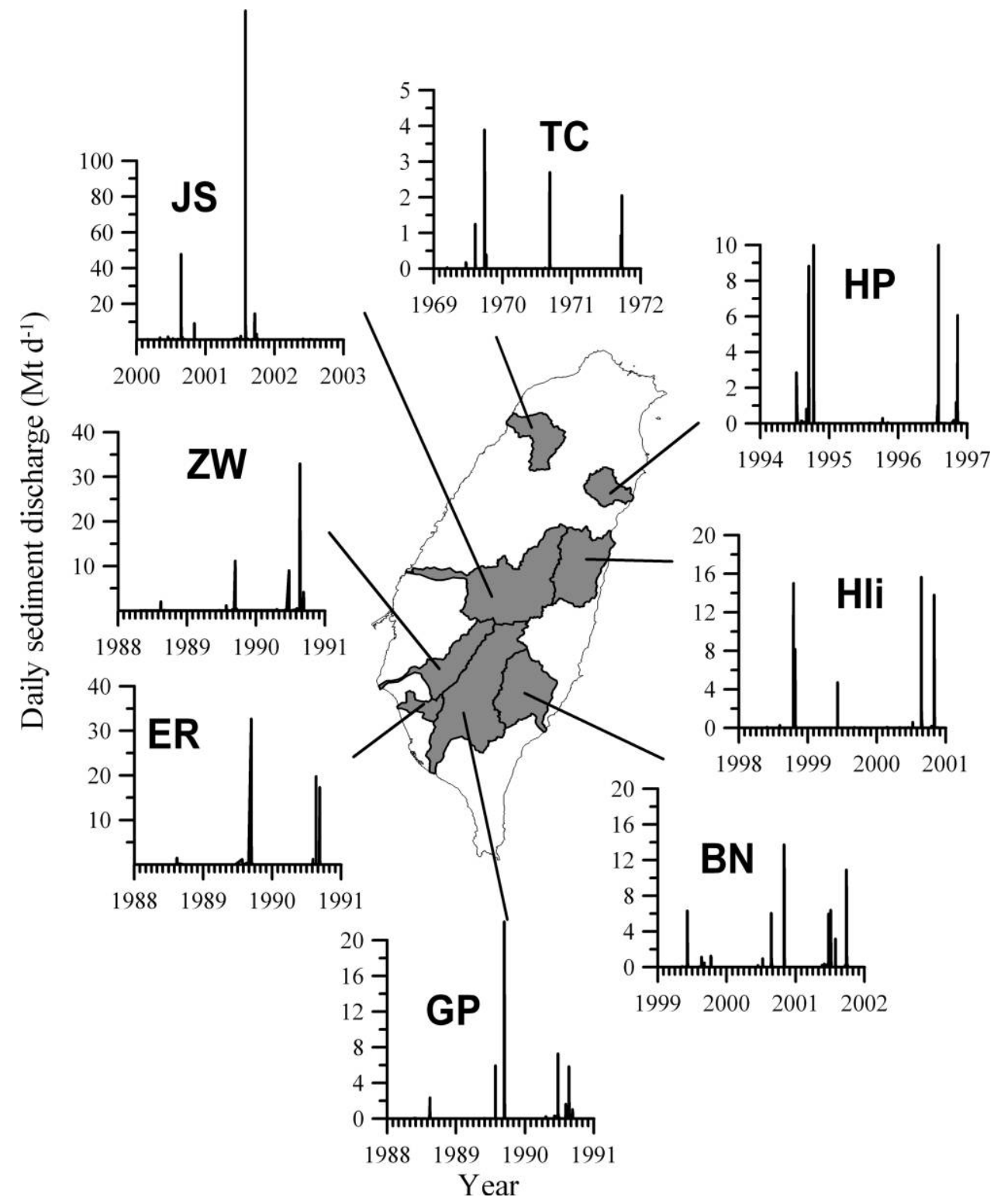

Figure 7. Examples of temporal variation of daily sediment load for three consecutive years. River names: $B N=$ Beinan, $E R=$ Erren, $G P=$ Gaoping, $H l i=$ Hualien, $H P=$ Hoping, $I S=$ Jhuoshuei, $T C=$ Toucian, and $Z W=$ Zengwun. 
nual sediment export. In fact, the magnitude and frequency of typhoon-related events almost always determine the annual total sediment flux. For example, no typhoon visited Taiwan in 1999 and thus no discharge peak occurred that year for the Jhuoshuei River.

In addition to typhoon-generated floods, changing landscape conditions can regulate the amount of sediment eroded and transported by a river. Disturbances by earthquakes (Dadson et al. 2005) and human activity (Kao and Liu 1996, 2001, 2002) have significant effects on sediment supply and discharge and consequently on sediment production due to changes in vegetation cover. During
Typhoon Toraji, after the Chi-Chi earthquake (1999), for instance, the Jhuoshuei River was calculated to have a $Q_{\mathrm{c}}$ of $130 \mathrm{~g} \mathrm{~L}^{-1}$ at a discharge of $10,000 \mathrm{~m}^{3} \mathrm{~s}^{-1}$ (Dadson et al. 2004), whereas during Super-Typhoon Herb in 1996 a similar discharge showed a $Q_{\mathrm{c}}$ of "only" $100 \mathrm{~g} \mathrm{~L}^{-1}$ (Milliman and Kao 2005); the difference may reflect the erosion of earthquake-induced landslide scars and deposits.

Hyperpycnal Events. All Taiwanese rivers are responsive to episodic events (figs. 4, 7), but hyperpycnal events tend to be unequally distributed both spatially and temporally. The WRA, for instance, has monitored no hyperpycnal events in either the Dajia or Beigang rivers in the northwestern part of

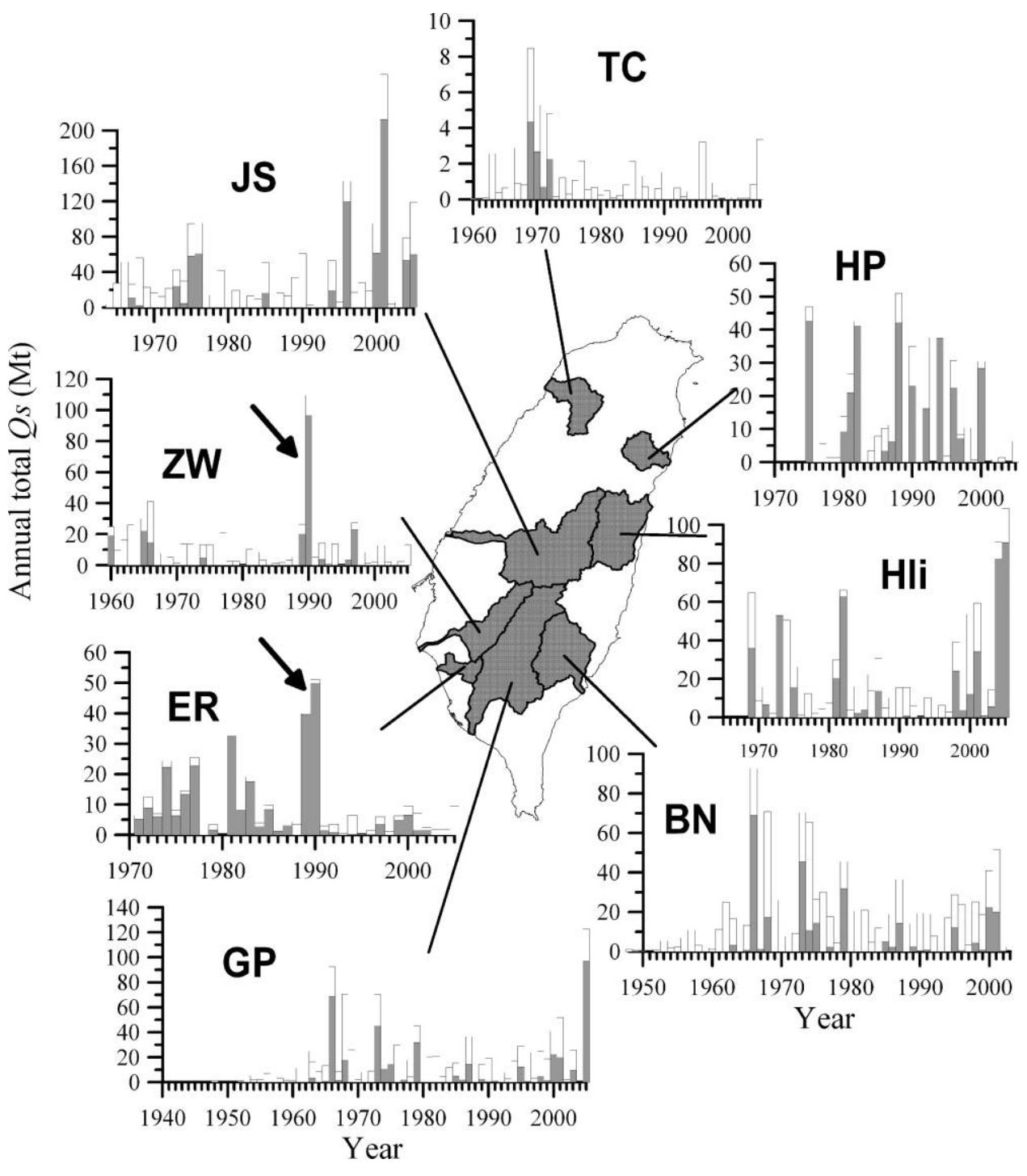

Figure 8. Interannual variability of sediment load $\left(Q_{s}\right.$, in $\left.M t y r^{-1}\right)$. Red color stands for the contribution from hyperpycnal flow. River names: $B N=$ Beinan, $E R=$ Erren, $G P=$ Gaoping, $H l i=$ Hualien, $H P=$ Hoping, $J S=$ Jhuoshuei, $T C=$ Toucian, and $Z W=$ Zengwun. 
the island. Of the 678 collective years for which we have data, hyperpycnal events in the other 14 rivers have been observed in 134 years (20\%; table 3 ; fig. 8). Most events lasted no more than a few tens of hours, and over the period of WRA monitoring, they have accounted for only $0.7 \%$ of the cumulative time but transported $35 \%$ of the cumulative sediment load. Apparently, hyperpycnal events are the main contributor to high sediment discharge years (fig. 8). Interestingly, the most hyperpycnal rivers also have the highest sediment yields (fig. 9; table 3), indicating that the level of hyperpycnal activity directly reflects the rate of landscape denudation.

Moreover, hyperpycnal rivers tend to be more episodic: in those rivers in which $\sim 40 \%$ or more of their long-term sediment load has been at hyperpycnal concentrations, $75 \%$ of it has occurred in $<1 \%$ of the cumulative time (red and brown watersheds in fig. 10), whereas rivers whose hyperpycnal events account for $<20 \%$ of cumulative load have required $4 \%-6 \%$ of the cumulative time to transport $75 \%$ of their sediment loads (blue watersheds, fig. 10). The Erren River, the most turbid Taiwanese river, has experienced hyperpycnal events in 26 years of its 35-year record since 1971, and these events accounted for more than $80 \%$ of its cumu- lative load in that period (table 3). Over the 29 years of Hoping River data, hyperpycnal events occurred in 13 years, accounting for $69 \%$ of the river's cumulative load (fig. 8).

Human Activities. According to their BQART model, Syvitski and Milliman (2007) concluded that globally anthropogenic factors account for $16 \%$ of sediment loads. While human activities, particularly land-use practices, may have a greater impact on the highly erosive Taiwanese watersheds, many of the river records on Taiwan are not sufficiently long to delineate the shift from natural to anthropogenically enhanced from natural sediment fluxes. Accordingly, translating present-day sediment fluxes into long-term denudation rates (Hartshorn et al. 2002; Dadson et al. 2003) is misleading at best. Because eastern river watersheds have been exposed to accelerated human activity since the 1960s, the 50-yr records for the Beinan and Lanyang rivers can help quantify the impact of human activity.

The Lanyang River, in the northeastern corner of the island, has seen several abrupt changes in sediment discharge, representing a combination of short-term impacts from construction and longerterm impacts of agricultural expansion (Kao and Liu
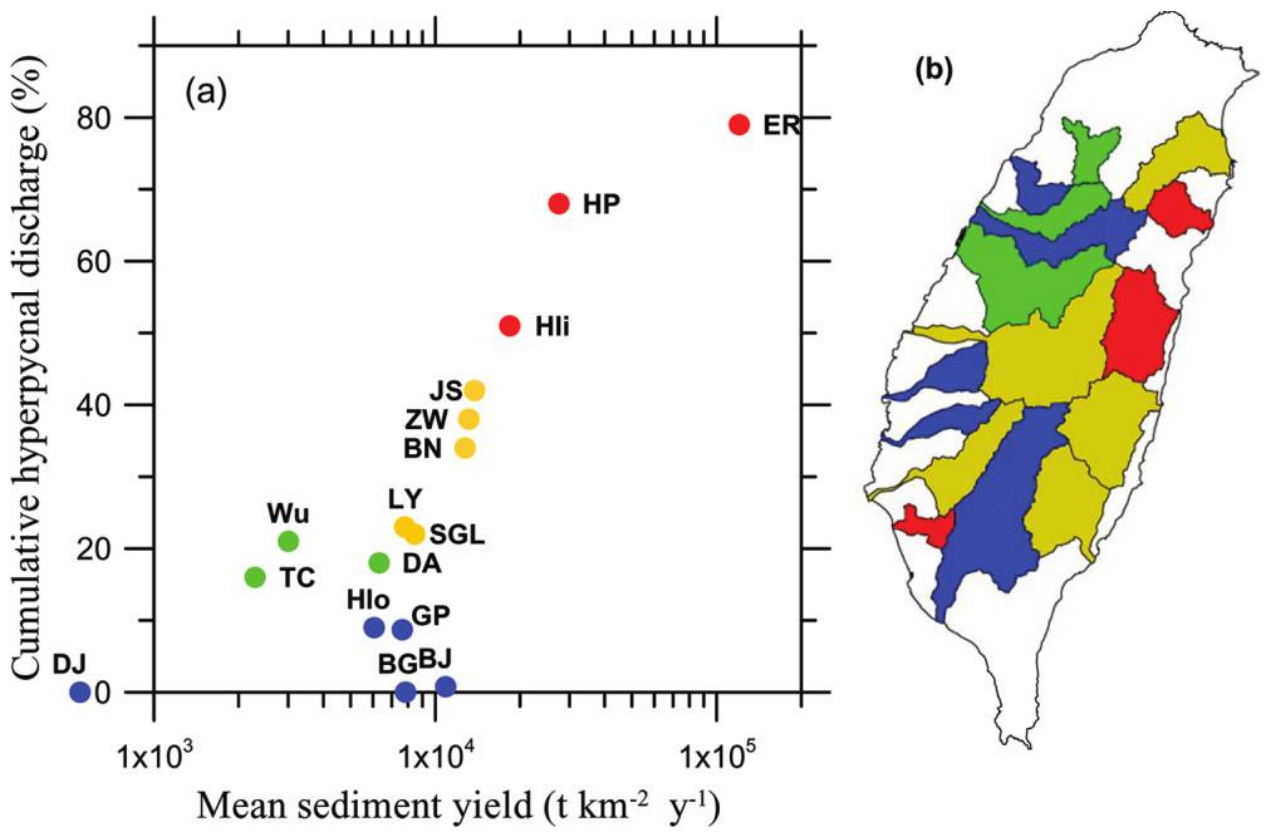

Figure 9. a, Cumulative percent hyperpycnal flow in total sediment discharge against sediment production per unit area (in $\mathrm{T} \mathrm{km}^{-2} \mathrm{yr}^{-1}$ ) for $>100 \mathrm{~m}$ elevations for 16 rivers. Values are based on full record periods. River names: $B G=$ Beigang, $B J=$ Bajhang,$B N=$ Beinan, $D A=$ Daan, $D J=$ Dajia, $E R=$ Erren, $G P=$ Gaoping, Hli $=$ Hualien, $H l o=$ Houlong, $H P=$ Hoping, $I S=$ Jhuoshuei, $L Y=$ Lanyan, $S G L=$ Siouguluan, $T C=$ Toucian, $W u=W u, \quad$ nd $Z W=$ Zengwun. $b$, Watersheds are colored as categorized by criteria in $a$. 


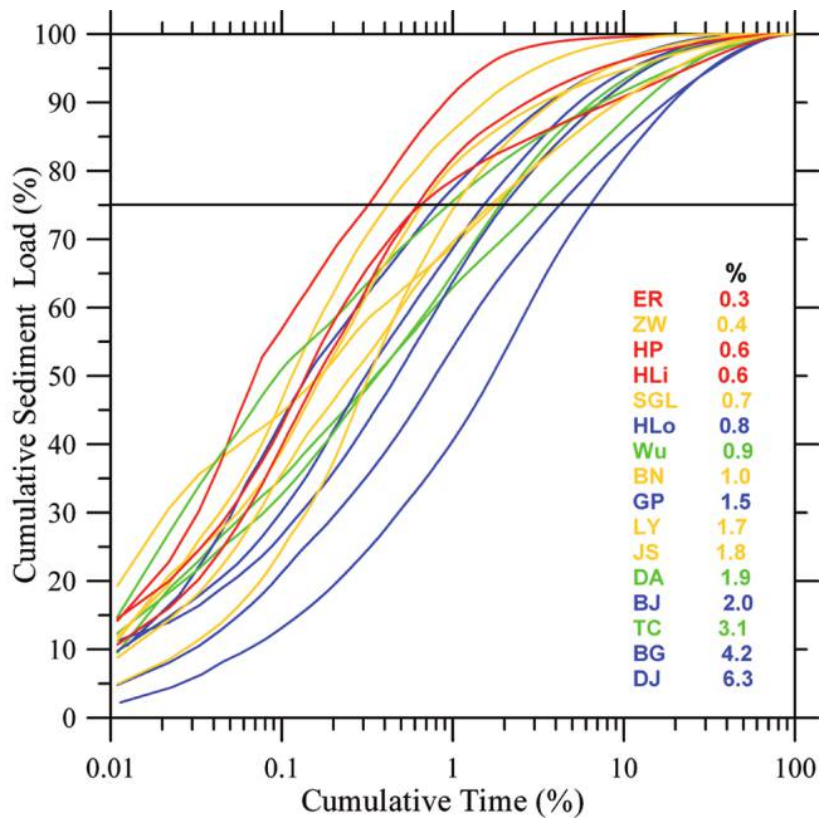

Figure 10. Curves of percent cumulative sediment load against percent cumulative time over entire record periods for 16 rivers. Red, brown, green, and blue curves represent, respectively, rivers requiring $<0.5 \%,<1 \%,<4 \%$, and $>4 \%$ cumulative time to reach $75 \%$ cumulated load. Colored watersheds categorized by same criteria. River names: $B G=$ Beigang, $B J=$ Bajhang, $B N=$ Beinan, $D A=$ Daan, $D J=$ Dajia, $E R=$ Erren, $G P=$ Gaoping, $H l i=$ Hualien, $H L O=$ Houlong,$\quad H P=$ Hoping,$\quad I S=$ Jhuoshuei,$L Y=$ Lanyan, $S G L=$ Siouguluan, $T C=$ Toucian, $W u=W u$, and $Z W=$ Zengwun.

2002). Before road construction began in 1958 (fig. 11), the average annual sediment load was 2.6 $\mathrm{Mt} \mathrm{yr}^{-1}$. Following massive road construction projects in the late 1950s and early 1960s, annual sediment loads increased to $\sim 21 \mathrm{Mt} \mathrm{yr}^{-1}$ for several years before returning to preconstruction levels. Between 1975 and 1980, agriculture activity expanded in the upper reaches of the river, generating an 80-fold increase in sediment yield (Kao and Liu 2002), which again translated to a 10 -fold increase at the river's mouth. If we assume the mean annual sediment discharge before 1958 represents a more or less undisturbed watershed, then $\sim 65 \%$ of the 358 Mt post-1958 sediment discharge was human induced (fig. 11).

The Beinan River experienced one major shift in sediment discharge after 1960 (fig. 11), the mean annual load rate increasing from $2.8 \mathrm{Mt} \mathrm{yr}^{-1}$ (1949$1960)$ to $23 \mathrm{Mt} \mathrm{yr}^{-1}$ (post-1960). Sediment yield increased from a pre-1960 value of $1600 \mathrm{t} \mathrm{km}^{-2} \mathrm{yr}^{-1}$ to $13,000 \mathrm{t} \mathrm{km}^{-2} \mathrm{yr}^{-1}$ thereafter. Although we can find no specific reason for the abrupt change, we suspect that it reflects increased agricultural use in the Beinan watershed.

We also should note a decrease in the Zengwun's sediment load between in 1966 and 1990, followed by a dramatic increase in 1990 (fig. 11), in which sediment discharge jumped from a long-term mean

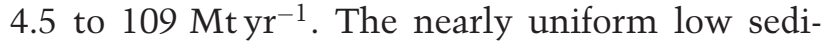
ment load $\left(<4 \mathrm{Mtyr}^{-1}\right)$ between 1976 and 1989 (delineated in fig. 11) may reflect the 1976 commissioning of the Zengwun dam. The $>20$-fold increase in 1990 was noted also in the nearby Yanshui (not
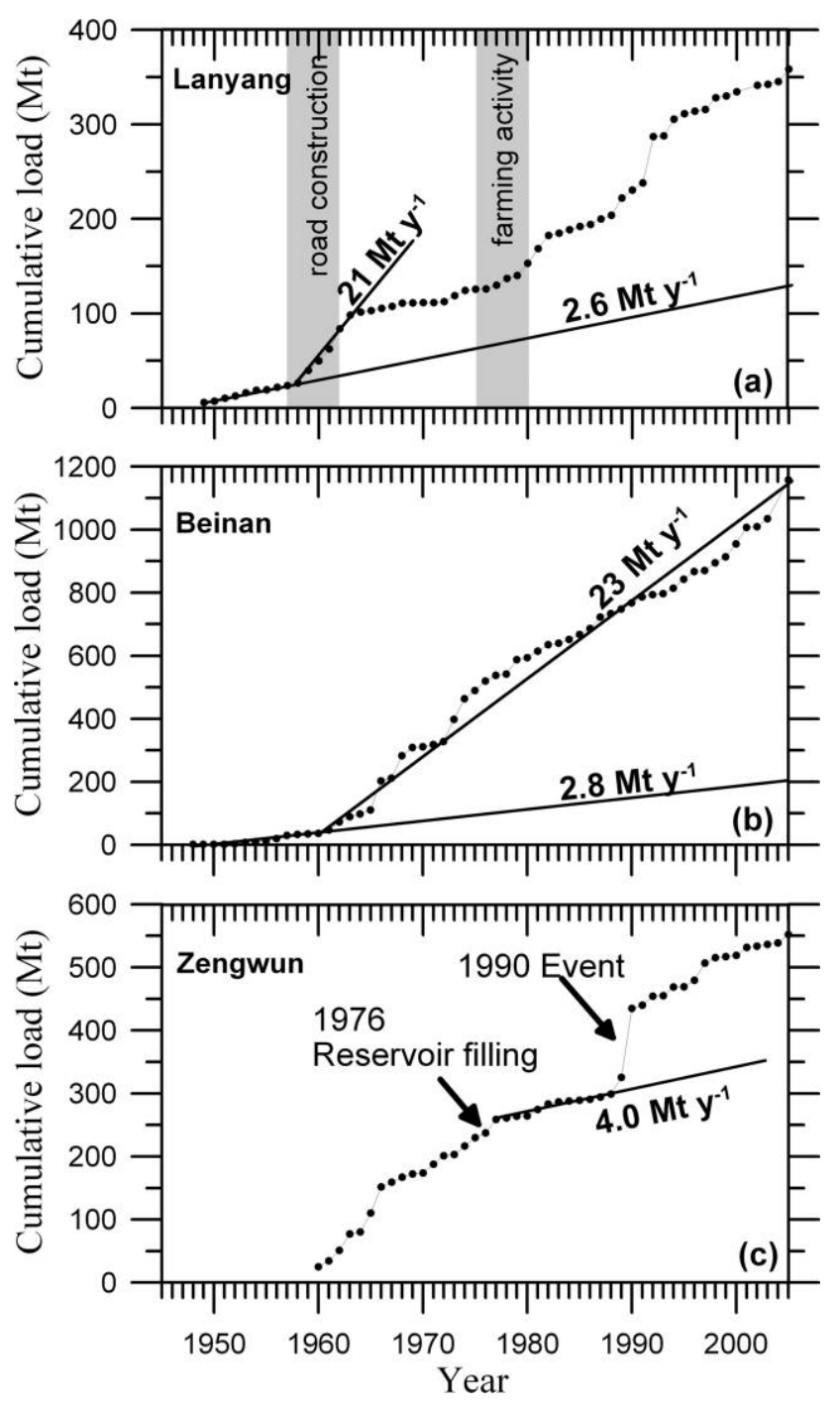

Figure 11. Cumulative sediment loads for the Lanyang $(a)$, Beinan $(b)$, and Zengwun $(c)$ rivers. Shadow zones represent periods of extensive road construction and following up agricultural activities. Arrows in $c$ mark 1976 reservoir filling and 1990 high-discharge event (see text). Mean loads during predisturbance are shown. 
identified in fig. 1) and Erren rivers; a measured concentration of $550 \mathrm{~g} \mathrm{~L}^{-1} \delta$ in the latter (August 21, 1990), at a discharge of only $472 \mathrm{~m}^{3} \mathrm{~s}^{-1}$, is the highest $Q_{c}$ ever measured in a Taiwanese river. The following year, suspended sediment concentrations and loads returned to normal, and over the next $10 \mathrm{yr}$, annual sediment discharge averaged slightly less than $10 \mathrm{Mtyr}^{-1}$. We are not sure of the origin of this one-time pulse in suspended sediment, but as it occurred in a number of adjacent watersheds, we suspect that it may represent the impact of construction of a major north-south highway during this period.

To some extent, the differences in sediment yields also may be explained partly by the location, timing, and severity of earthquakes. The only earthquake experienced by the Touchien River watershed, for example, preceded the one period (19691972) in which sediment loads exceeded $4 \mathrm{Mt} \mathrm{yr}^{-1}$ (cf. figs. 12 and 8). Similarly, the Jhoushuei's highest loads occurred after 1991, in part because of typhoons Herb, Toraji, and Mendulle but also following several major earthquakes, including the Chichi earthquake of 1999 (Dadson et al. 2005; Milliman et al. 2007). The very high yields of eastern rivers also may be explained in part by frequent onshore and offshore earthquakes (fig. 12), confirming the

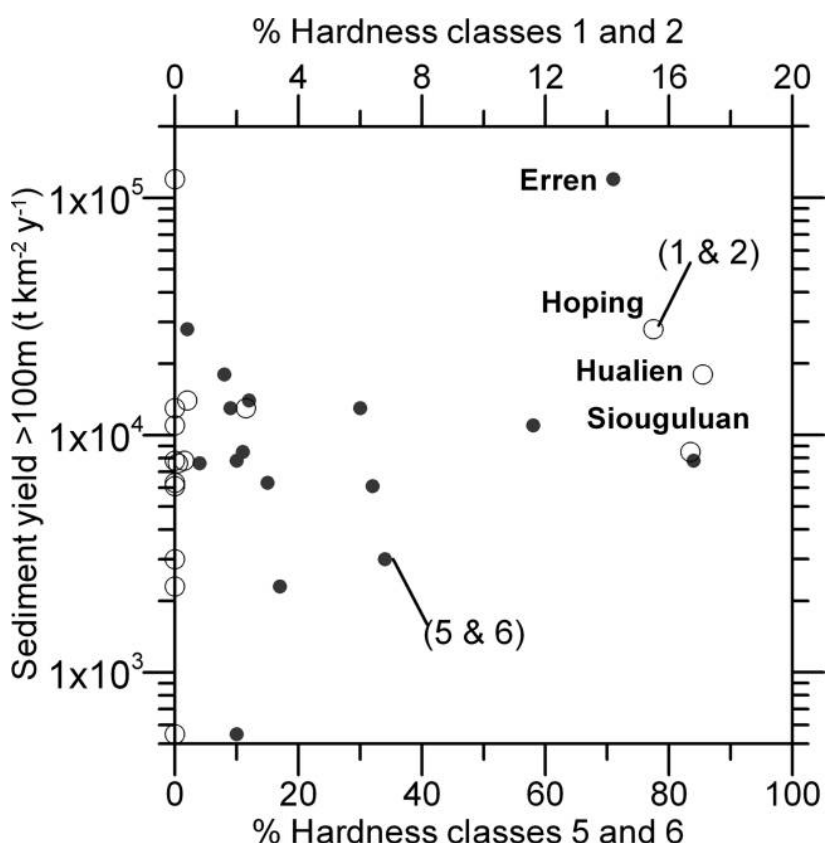

Figure 12. Correlation of sediment yield and lithology (in percent area of hardness classes) for watershed $>100 \mathrm{~m}$ elevation for the 16 Taiwanese rivers. impact of rapid uplift in young tectonically active mountains (e.g., Montgomery and Brandon 2002).

While the impact of human activities-both increasing and decreasing sediment loads and yieldscannot be denied, we also should point out that post-Last Glacial Maximum (LGM) sedimentation rates in the coastal plain of western Taiwan /Cheng et al. 2001; Hsieh et al. 2006, unpublished manuscript) and in the Taiwan Strait submarine delta located off the Jhuoshuei River (Liu et al., unpublished manuscript) suggest that post-LGM sediment fluxes from western rivers have averaged at least $80 \mathrm{Mt} \mathrm{yr}^{-1}$, a value not too different from the collective present-day discharge from these rivers, a point also made by Liu et al. (unpublished manuscript). In other words, based on available data, present-day sediment fluxes from western rivers may not reflect the anthropogenically accelerated denudation noted in the eastern rivers. We cannot explain this apparent inconsistency.

\section{Concluding Remarks}

The high sediment discharge and yields of Taiwanese rivers, first observed by Li (1976) more than $30 \mathrm{yr}$ ago reflect the effects of high mountains, steep gradients, frequent earthquakes, erodible lithology, and heavy rainfall. On average, the 16 rivers discussed in this article annually discharge 180 $\mathrm{Mtyr}^{-1}$, with an island-wide sediment yield of $9500 \mathrm{t} \mathrm{km}^{-2} \mathrm{yr}^{-1}$ although cumulative annual loads have ranged from 16 to $440 \mathrm{Mt}$. Three other factors not emphasized by Li also play important roles in determining the high sediment yield of Taiwanese rivers: (1) episodic events, particularly typhooninduced rains, can dictate short- and long-term water and sediment discharge; (2) the sediment transported during these events often occurs at hyperpycnal concentrations; and (3) anthropogenic alteration of the landscape has locally increased sediment erosion-and transport-considerably.

The relative importance of environmental factors controlling sediment yield and discharge, however, varies greatly from river to river. The high sediment yield in the Erren River $\left(71,000 \mathrm{t} \mathrm{km}^{-2} \mathrm{yr}^{-1}, \sim 450\right.$ fold greater than the global mean), apparently reflects erodible rocks (fig. 13; table 1) rather than elevation $(460 \mathrm{~m})$, gradient $(0.7 \%)$, or runoff $\left(1700 \mathrm{~mm} \mathrm{yr}^{-1}\right)$. In contrast, the high sediment yields in the eastern Hoping, Hualien, and Beinan rivers $\left(27,000,17,000\right.$, and $13,000 \mathrm{t} \mathrm{km}^{-2} \mathrm{yr}^{-1}$, respectively) appear to be determined primarily by steep gradients $(3.7 \%-4.4 \%)$ and higher runoff (1900-2100 $\left.\mathrm{mm} \mathrm{yr}^{-1}\right)$ as well as the impacts from human activities. Three watersheds with very high 


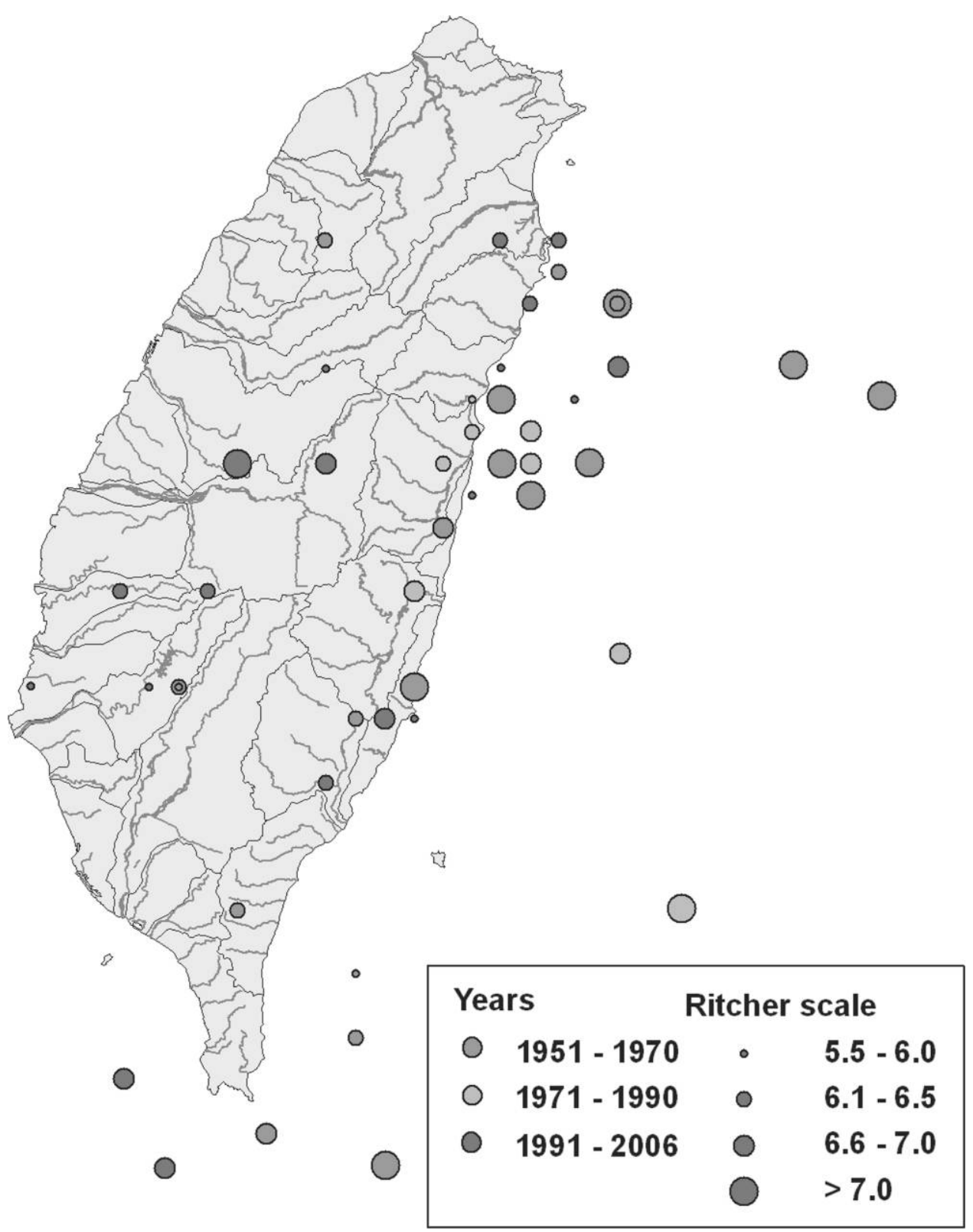

Figure 13. Location and magnitude (Richter scale) of earthquakes that occurred in and around Taiwan, 1951 to present. Note the frequent earthquakes in the east and the relative lack of earthquakes in the northwest and southwest parts of Taiwan.

sediment yield (Hoping, Hualien, and Siouguluan) rivers have some of the lowest percentages of most easily erodible lithologies $(2 \%-11 \%)$ and highest percentages of hard lithologies $(16 \%-17 \%)$. In contrast, the Beigang has the largest coverage of erodible rocks $(84 \%)$ but one of the lowest sediment yields (2300 t km ${ }^{-2} \mathrm{yr}^{-1}$; fig. 13; table 1). Similarly, a river with low runoff and low gradient (Jhoushuei, $1200 \mathrm{~mm} \mathrm{yr}^{-1}, 1.8 \%$ ) has about twice the sediment yield $\left(13,000 \mathrm{t} \mathrm{km}^{-2} \mathrm{yr}^{-1}\right)$ of the Lanyang $(7800$ $\mathrm{t} \mathrm{km}^{-2} \mathrm{yr}^{-1}$ ) despite the latter having twice the runoff $\left(2400 \mathrm{~mm} \mathrm{yr}^{-1}\right)$ and nearly three times the gradient $(4.8 \%)$. Perhaps even more perplexing is the observation that although human activities have clearly elevated sediment loads and yields of eastern rivers, present-day sediment discharge from western rivers may not be significantly different from postLGM values. While the algorithms derived by Syvitski and Milliman (2007) have obvious global significance, their application of smaller rivers, par- 
ticularly those impacted by episodic events, such as typhoons (as stated by Syvitski and Milliman) must be treated with caution.

\section{A C K N O W L E D G M E N T S}

This study was supported by a grant to S. J. Kao from the National Science Council of Taiwan (NSC
96-2628-M-001-028) and various grants to J. D. Milliman from the U.S. National Science Foundation and Naval Oceanographic Office. We thank the Water Resources Agency, Taiwan, for data provision. Constructive comments from D. E. Walling and an anonymous reviewer are deeply appreciated. We also are grateful to T. Y. Lee and C. W. Kuo for their help with data analysis.

\section{R E F E R E N C E S C I T E D}

Adams, J. 1980. High sediment yields from major rivers of the western Southern Alps, New Zealand. Nature 287: 88-89, doi:10.1038/287088b0.

Carey, A. E.; Nezat, C. A.; Lyons, W. B.; Kao, S. J.; Hicks, D. M.; and Owen, J. S. 2002. Trace metal fluxes to the ocean: the importance of high-standing oceanic islands. Geophys. Res. Lett. 29:2099, 10.1029/ 2002GL015690.

Cheng, P. H.; Yang, C. H.; Cheng, W. S.; Shieh, J. S.; and Liu, T. K. 2001. An electrostratigraphic study of the Chiayi Coastal Plain, southwestern Taiwan. West. Pac. Earth Sci. 1:85-98.

Dadson, S. J. 2004. Erosion of an active mountain belt. $\mathrm{PhD}$ thesis, Department of Earth Sciences, University of Cambridge.

Dadson, S. J.; Hovius, N.; Chen, H.; Dade, W. B.; Hsieh, M. L.; Willett, S. D.; Hu, J. C.; et al. 2003. Links between erosion, runoff variability and seismicity in the Taiwan orogen. Nature 426:648-651.

Dadson, S. J.; Hovius, N.; Chen, H.; Dade, W. B.; Lin, J. C.; Hsu, M. L.; Lin, C. W.; et al. 2004. Earthquaketriggered increase in sediment delivery from an active mountain belt. Geology 32:733-736.

Dadson, S. J.; Hovius, N.; Pegg, S.; Dade, W. B.; and Horng, M. J. 2005. Hyperpycnal river flows from an active mountain belt. J. Geophys. Res. 110:F04016.

Fournier, F. 1949. Les factuers climatiques de l'erosion du sol. Assoc. Geog. Fr. Bull. 203:97-103.

1960. Climat et érosion. Paris, Presses Universitaires de France, $201 \mathrm{p}$.

Fuller, W. C.; Willett, S. D.; Hovius, N.; and Slingerland, R. L. 2003. Erosion rates for mountain basins: new determinations from suspended sediment records and a stochastic model of their temporal variation. I. Geol. 111:71-87.

Griffiths, G. A. 1981. Some suspended sediment yields from South Island catchments, New Zealand. Water Res. Bull. 17:662-671.

Hartshorn, K.; Hovius, N.; Dade, W. B.; and Slingerland, R. L. 2002. Climate-driven bedrock incision in an active mountain belt. Science 297:2036-2038.

Ho, C. S. 1986. An introduction to the geology of Taiwan: explanatory text of the geological map of Taiwan. Taipei, Central Geological Survey, Ministry of Economic Affairs.
Holeman, J. N. 1968. Sediment yield of major rivers of world. Water Resour. Res. 4:737.

Horowitz, A. J. 2003. An evaluation of sediment rating curve for estimating suspended sediment concentration for subsequent flux calculations. Hydrol. Process. 17:3387-3409.

Hovius, N.; Stark, C. P.; Chu, H. T.; and Lin, J. C. 2000. Supply and removal of sediment in a landslidedominated mountain belt: Central Range, Taiwan. I. Geol. 108:73-89.

Hsieh, M. L.; Lai, T. H.; Wu, L. C.; Lu, W.; Liu, H. T.; and Liew, P. M. 2006. Eustatic sea-level change of 11-5 ka in western Taiwan, constrained by radiocarbon dates of core sediments. Terres. Atmos. Ocean. Sci. 17: 353-370.

Jansen, P. P.; van Bendegom, L.; van den Berg, J.; de Vries, M.; and Zanen, A. 1979. Principles of river engineering: the non-tidal alluvial river. London, Pitman.

Kao, S. J.; Lee, T. Y.; and Milliman, J. D. 2005. Calculating highly fluctuated suspended sediment fluxes from mountainous rivers in Taiwan. Terres. Atmos. Ocean. Sci. 16:653-675.

Kao, S. J., and Liu, K. K. 1996. Particulate organic carbon export from a subtropical mountainous river (LanyangHsi) in Taiwan. Limnol. Oceanogr. 41:1749-1757.

- 2001. Estimating the suspended sediment load by using the historical hydrometric record from the Lanyang-Hsi watershed. Terres. Atmos. Ocean. Sci. 12:401-414.

- 2002. Exacerbation of erosion induced by human perturbation in a typical Oceania watershed: insight from 45 years of hydrological records from the Lanyang-Hsi River, northeastern Taiwan. Global Biogeochem. Cycles 16, doi: 10.1029/2000GB001334.

Kao, S. J.; Shiah, F. K.; Wang, C. H.; and Liu, K. K. 2006. Efficient trapping of organic carbon in sediments on the continental margin with high fluvial sediment input off southwestern Taiwan. Continental Shelf Res. 26:2520-2537.

Leithold, E. L.; Blair, N. E.; and Perkey, D. W. 2006. Geomorphic controls on the age of particulate organic carbon from small mountainous and upland rivers. Global Biogeochem. Cycles 20, GB3022, doi:10.1029/ 2005 GB002677. 
Li, Y. H. 1976. Denudation of Taiwan island since the Pliocene epoch. Geology 4:105-107.

Lisitzin, A. P. 1972. Sedimentation in the world ocean. Soc. Econ. Paleontol. Mineral. Spec. Publ. 17, 218 p.

Liu, T. K. 1982. Tectonic implications of fission track ages from the Central Range, Taiwan. Geol. Soc. China Proc. 25:22-37.

Lyons, W. B.; Nezat, C. A.; Carey, A. E.; and Hicks, D. M. 2002. Organic carbon fluxes to the ocean from highstanding islands. Geology 30:443-446.

Meybeck, M.; Laroche, L.; Durr, H. H.; and Syvitski, J. P. M. 2003. Global variability of daily total suspended solids and their fluxes in rivers. Glob. Planet. Change 39:65-93.

Milliman, J. D. 1995. Sediment discharge to the ocean from small mountainous rivers: the New Guinea example. Geo-Mar. Lett. 15:127-133.

Milliman, J. D.; Farnsworth, K. L.; and Albertin, C. S. 1999. Flux and fate of fluvial sediments leaving large islands in the East Indies. I. Sea Res. 41:97-107.

Milliman, J. D., and Kao, S. J. 2005. Hyperpycnal discharge of fluvial sediment to the ocean: impact of SuperTyphoon Herb (1996) on Taiwanese Rivers. I. Geol. 113:503-516.

Milliman, J. D.; Lin, S.; Kao, S. J.; Liu, J. P.; Liu, C. S.; Chiu, J. K.; and Lin, Y. C. 2007. Short-term changes in seafloor character due to flood-derived hyperpycnal discharge: Typhoon Mindulle, Taiwan, July 2004. Geology 35:779-782.

Milliman, J. D., and Syvitski, J. P. M. 1992. Geomorphic/ tectonic control of sediment discharge to the ocean: the importance of small mountainous rivers. I. Geol. 100:525-544.

Montgomery, D. R., and Brandon, M. T. 2002. Topographic controls on erosion rates in tectonically active mountain ranges. Earth Planet. Sci. Lett. 201:481-489.
Mulder, T., and Syvitski, J. P. M. 1995. Turbidity currents enerated at river mouths during exceptional discharges to the world oceans. I. Geol. 103:285-299.

Mulder, T.; Syvitski, J. P. M.; Migeon, S.; Faugeres, J. C.; and Savoye, B. 2003. Marine hyperpycnal flows: initiation, behavior and related deposits. A reviewMar. Petrol. Geol. 20:861-882.

Nittrouer, C. A.; Brunskill, G. J.; and Figueiredo, A. G. 1995. Importance of tropical coastal environments. Geo-Mar. Lett. 15:121-126.

Pickup, G. 1980. Hydrologic and sediment modeling studies in the environmental-impact assessment of a major tropical dam project. Earth Surf. Proc. Landf. 5: 61-75.

Summerfield, M. A., and Hulton, N. J. 1994. Natural controls on fluvial denudation rates in major world drainage basins. I. Geophys. Res. 99:13,871-13,883.

Syvitski, J. P. M., and Milliman, J. D. 2007. Geology, geography, and humans battle for dominance over the delivery of fluvial sediment to the coastal ocean. I. Geol. 115:1-19.

Syvitski, J. P. M., and Morehead, M. D. 1999. Estimating river-sediment discharge to the ocean: application to the Eel margin, northern California. Mar. Geol. 154: $13-28$.

Walling, D. E. 1977. Assessing the accuracy of suspended sediment rating curves for a small basin. Water Resour. Res. 13:531-538.

. 1983. The sediment delivery problem. I. Hydrol. 65:209-237.

- 1999. Linking land use, erosion and sediment yields in river basins. Hydrobiologia 410:223-240.

Warrick, J. A., and Milliman, J. D. 2003. Hyperpycnal sediment discharge from semiarid southern California rivers: implications for coastal sediment budgets. Geology 31:781-784. 